\title{
IMPROVING WATER USE EFFICIENCY OF ANNUAL CROPS IN THE RAINFED FARMING SYSTEMS OF WEST ASIA AND NORTH AFRICA
}

\author{
By P. J. M. COOPER, P. J. GREGORY†, D. TULLY and H. C. HARRIS \\ Farming Systems Programme, ICARDA, PO Box 5466, Aleppo, Syria and \\ $\dagger$ Department of Soil Science, University of Reading, London Road, \\ Reading, RG1 $5 A Q$ England
}

(Accepted 1 August 1986)

\begin{abstract}
SUMMAR Y
Farming systems in west Asia and north Africa have evolved to cope with the problems of highly variable and, frequently, chronically deficient rainfall. Cereals (mainly wheat and barley) are the dominant arable crops with food legumes (chickpea, lentil and faba bean) occupying only 5 to $10 \%$ of the area planted to cereals. Livestock is closely integrated into the farming system and crop production practices often reflect the importance of animals as a major source of income, particularly on the smaller farms. Soils of the region are predominantly calcareous, frequently phosphate deficient, and their depth and texture are important in determining the maximum amount of water that can be stored which, in turn, may determine the effective length of the growing season.

Rain falls mainly during the winter months so that crops must often rely on stored soil moisture when they are growing most rapidly. Analysis of equations relating crop growth and water use shows that there are three ways in which the 'water use efficiency' of dry matter production can be increased. First, the amount of dry matter produced per unit of water transpired might be increased; second, if the water supply is limited, the amount of water transpired might be increased relative to evaporation from the soil surface; and third, the total amount of water used might be increased to produce extra growth provided that this results in increased transpiration rather than simply increasing evaporation from the soil surface.

These three possible routes to increased crop growth are reviewed in relation to possible improvements in water management and crop genotypes in the Mediterranean environment. Scope for improving transpiration efficiency is limited although genotypic differences exist and may be useful in the future. More immediately, changes in crop management, such as applications of fertilizer, improved tillage and better weed control, will all increase the amount of water transpired. Application of mulches will also reduce evaporation from the soil surface but crop residues are usually eaten by livestock and are, therefore, often unavailable.

The barley/livestock farming system of west Asia is used as a case study to illustrate how the Farming Systems Programme of ICARDA has developed on-farm research programmes of direct relevance to current farming systems. Research on experimental sites directed at improving water use efficiency has been developed into on-farm trials and into collaborative trials with the Syrian Soils Directorate.
\end{abstract}

P. J. M. Cooper, P. J. Gregory, D. Tully y H. C. Harris: Mejorando la eficacia de utilización del agua de cultivos anuales en los sistemas de secano de Asia Occidental y Africa del Norte.

\section{RESUMEN}

Los sistemas agricolas de Asia Occidental y Africa del Norte han evolucionado para adaptarse a los problemas de la lluvia sumamente variable y, a menudo, de una deficiencia crónica. Los cultivos arables predominantes son los cereales (principalmente trigo y cebada), las legumbres alimenticias (garbanzo, lenteja y frijol común) ocupando sólo del 5 al $10 \%$ del área plantada con cereales. El ganado está estrechamente integrado al sistema agricola y las prácticas de producción de cultivos reflejan a menudo la importancia que tienen los animales como fuente de 
ingresos, especialmente en las haciendas menores. Los suelos de la región son predominantemente calcáreos, a menudo deficientes en fosfatos, y su profundidad y textura son factores importantes en la determinación de la máxima cantidad de agua que puede ser almacenada, lo cual puede a su vez determinar la duración efectiva de la estación.

Llueve principalmente durante los meses de invierno, por lo tanto, durante la época de más rápido crecimiento, los cultivos deben depender a menudo de la humedad almacenada en el suelo. El análisis de ecuaciones que relacionan el crecimiento del cultivo con el agua demuestra que hay tres maneras en que puede ser aumentada la 'eficacia de utilización del agua' en la producción de materia seca. Primero, puede ser aumentada la cantidad de materia seca producida por unidad de agua transpirada; segundo, si el suministro de agua está limitado, puede ser aumentada la cantidad de agua transpirada relativo a la evaporación de la superficie del suelo; y tercero, puede ser aumentada la cantidad total de agua utilizada para producir un crecimiento adicional, siempre que esto resulte en un aumento de la transpiración, y no aumente simplemente la evaporación de la superficie del suelo.

Se repasan estas tres posibilidades para aumentar el crecimiento del cultivo en relación a posibles mejoras en las gestión del agua y genotipos de cultivos en el ambiente mediterráneo. El campo para mejorar la eficacia de la transpiración es limitado, aunque existen diferencias genotípicas que puedan ser útiles en el futuro. Más inmediatamente, cambiogsen la gestión de cultivos, tales como la aplicación de fertilizantes, un mejor arado y una lucha contra las malezas más eficaz, aumentarán la cantidad de agua transpirada. La aplicación de coberturas también redujo la evaporación de la superficie del suelo, pero los restos del cultivo son generalmente comidos por el ganado y, por lo tanto, no están disponibles.

El sistema agricola de cebada/ganado del Asia Occidental se presenta como caso de investigación para ilustrar cómo el Programa de Sistemas Agrícolas [Farming Systems Programme] de ICARDA ha desarrollado programas de investigación, llevados a cabo en las haciendas mismas, directamente pertinentes a los sistemas agrícolas actuales. Las investigaciones en terrenos experimentales orientados hacia el mejoramiento de la eficacia de la utilización del agua se han desarrollado en pruebas en las haciendas mismas y en pruebas colaborativas con la Administración de Suelos de Siria [Syrian Soils Directorate].

\section{INTRODUCTION}

Agricultural systems first evolved in the Mediterranean basin over 10000 years ago in the fertile crescent of west Asia. During its history the region has made important contributions to world agriculture, having been the centre of origin of many major cereal and legume crops, and of the early domestication of sheep and goats.

The development of agriculture from these early times, through the period of Roman administration, the subsequent periods of Arab and Turkish domination, and the more recent colonial period of the nineteenth and twentieth centuries has been reviewed elsewhere (White, 1963, 1970; Watson, 1974) and the evolution and characteristics of existing farming systems have been described in some detail (Grigg, 1974; Aschmann, 1977; Oram, 1979; Gibbon, 1981; Tully, 1986). McWilliam (1981) notes that the problem facing farmers throughout this period of evolution has remained the same, namely that of farming in an environment characterized by highly variable and often chronically deficient rainfall. Many of the strategies developed to 'buffer' against this uncertainty of rainfall are still common features of current farming systems, and it is perhaps ironic that agricultural scientists of today are rediscovering improved crop rotational systems and fallow practices similar to those of the Roman empire more than 2000 years ago (White, 1970).

Whilst the climate, soils, crops and livestock which form the essential edaphic and biological components of the farming systems have probably changed little 
over time, both the social and economic environments of farmers are today radically different. National policies emphasizing industrialization, pricing policies favouring urban populations, and neglect of both basic services and farming in rural areas have led to stagnation of agriculture and emigration of the farming community. Throughout the region the relative importance of agriculture has declined in recent decades, and in most countries food production per capita has also declined, yet the population is increasing (Tully, 1986). It has been estimated that by 1990 the countries within the Mediterranean basin will face an annual 30-34 millon ton food deficit. It is clear that, in order to avoid this potentially disastrous situation, economic and stable gains in food production must be achieved through more efficient use of the region's most precious and yet uncertain resource, water.

In this review we highlight some of the important research on improving the water use efficiency of rainfed crops in arid winter rainfall environments which is of special relevance to the Mediterranean region, and illustrate how some of these principles are being successfully applied in a case study in northern Syria. Much of the research has been undertaken in regions of the world with similar climates, but contrasting agricultural systems, to those found in the Mediterranean region, for instance south and southwestern Australia and parts of the United States of America. In order that this and other research can be properly viewed in context, we start by summarizing some important aspects of the environment and farming systems of west Asia and north Africa which form the principal focus of this review.

\section{The climate}

The climate of the region has been discussed by several authors (de Brichambaut and Wallen, 1963; UNESCO/FAO, 1963; Meigs, 1964; Kassam, 1981). Rainfed crop production takes place against a background of limited, variable and often chronically deficient rainfall which largely occurs during the cool or cold winter months and to a lesser extent during the warmer spring months. The rainy seasons are followed by hot and arid summers. In general rain falls in greatest quantity near the sea but decreases rapidly in amount as one moves inland, and eventually rainfed farming systems give way to large expanses of arid grazing lands or desert. Rainfed farming, practised in areas receiving between approximately 200 and $600 \mathrm{~mm} \mathrm{year}^{-1}$ expected annual rainfall, occupies about $125 \times 10^{6}$ ha of land in west Asia and north Africa (Kassam, 1981). As will be discussed later, there is a broad association between expected rainfall and cropping systems. However, mean seasonal rainfall totals can only be used to give a general picture of potential productivity because of the large variability of rainfall both within and between seasons. Smith and Harris (1981) discuss the implications of variable rainfall on soil moisture dynamics and crop yields and highlight the importance of analysing long term rainfall records in terms of probability when assessing the implications of improved production practices. This approach has been applied by Keatinge et 
al. (1985) who illustrated the influence of variable rainfall regimes on the management of crop rotations at three contrasting locations in northern Syria. The seasonal distribution of rainfall, and the variablity associated with certain rainfall parameters, are illustrated for three locations of increasing aridity in NW Syria (Figs 1 and 2). Kassam (1981) pointed to a general relationship between seasonal rainfall totals and the length of the potential growing season (PGS) of crops. Clearly this parameter will be highly variable, for instance Smith and Harris (1981) estimated that the PGS at Aleppo in Syria, based on day degree requirements of crops and variability in available moisture, would vary between 60 and 180 days over the long term.

Temperature also plays an important role in determining the choice of suitable crops and their yield potential. During the cold winter months (December, January, February) temperatures (Table 1) are sub-optimal for crop growth, but rapidly rise during the spring months to super-optimal levels during the period in which crops are maturing (May, June). Continentality has a strong influence on winter temperatures and, in general, winters in west Asia are
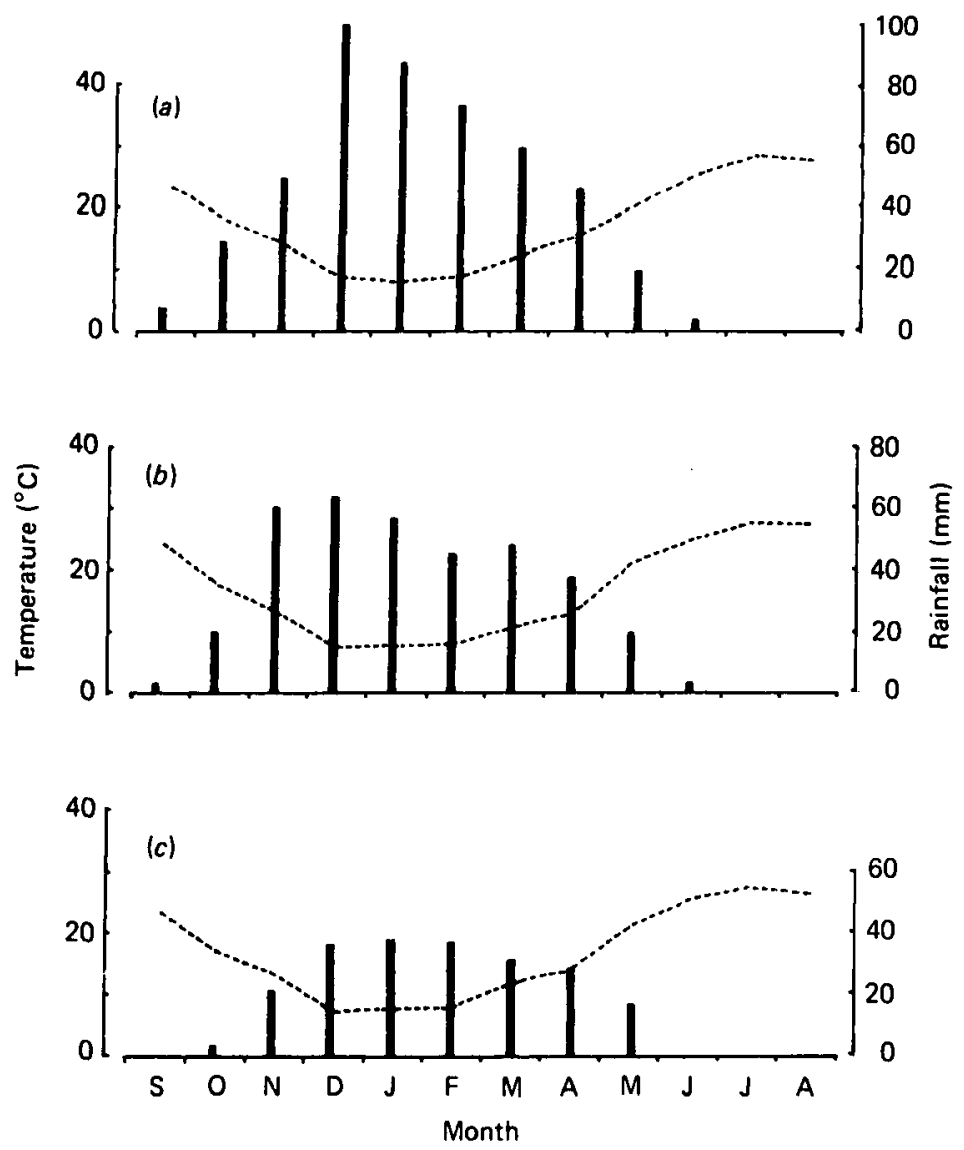

Fig. 1. Monthly mean temperatures (-..-) and rainfall totals for three locations in NW Syria: (a) Jindiress, $231 \mathrm{~m}, 36^{\circ} 23^{\prime} \mathrm{N}, 36^{\circ} 41^{\prime} \mathrm{E}$; (b) Aleppo, $350 \mathrm{~m}, 35^{\circ} 55^{\prime} \mathrm{N}, 36^{\circ} 55^{\prime} \mathrm{E}$; and (c) Khanasser, $350 \mathrm{~m}, 35^{\circ}$ $45^{\prime} \mathrm{N}, 37^{\circ} 32^{\prime} \mathrm{E}$. 
considerably colder than in north Africa. For instance, for the three locations described in Figs 1 and 2 an average of 48 (Khanasser), 35 (Aleppo) and 32 (Jindiress) frost days per season occurred in the period from 1980 to 1984 , absolute minimum temperatures of between $-6^{\circ} \mathrm{C}$ and $-10^{\circ} \mathrm{C}$ being common (ICARDA, 1985, p. 7). Elevation also has a marked effect on winter temperatures (see Tehran, Table 1); in west Asia and at high elevation in north Africa, frost can cause serious damage, particularly to winter sown pulses.

These cold temperatures, coupled with low radiation, high relative humidity and low windspeeds result in small rates of evaporative demand during the winter months. Furthermore, during these winter months, crop canopies are small and often the soil surface is only infrequently wetted (see Fig. $2 b$ and c). As a result, crop transpiration and soil evaporation rates are small, and seldom equal the potential evaporative demand. Rainfall in excess of crop evapotranspiration is thus stored within the soil profile. This is illustrated in Fig. 3, which gives the seasonal pattern of mean monthly rainfall and 0.5 potential evaporation for six locations in north Africa and west Asia. The value of 0.5 potential evapotranspiration approximates to the ratio of actual seasonal to potential seasonal evapotranspiration observed in several studies (e.g. Cooper et al., 1981) and has been used by other authors (Kassam, 1981). The shaded areas thus represent periods when rainfall is likely to exceed crop evapotranspiration so that storage of rainfall in the soil profile will occur. During the spring and
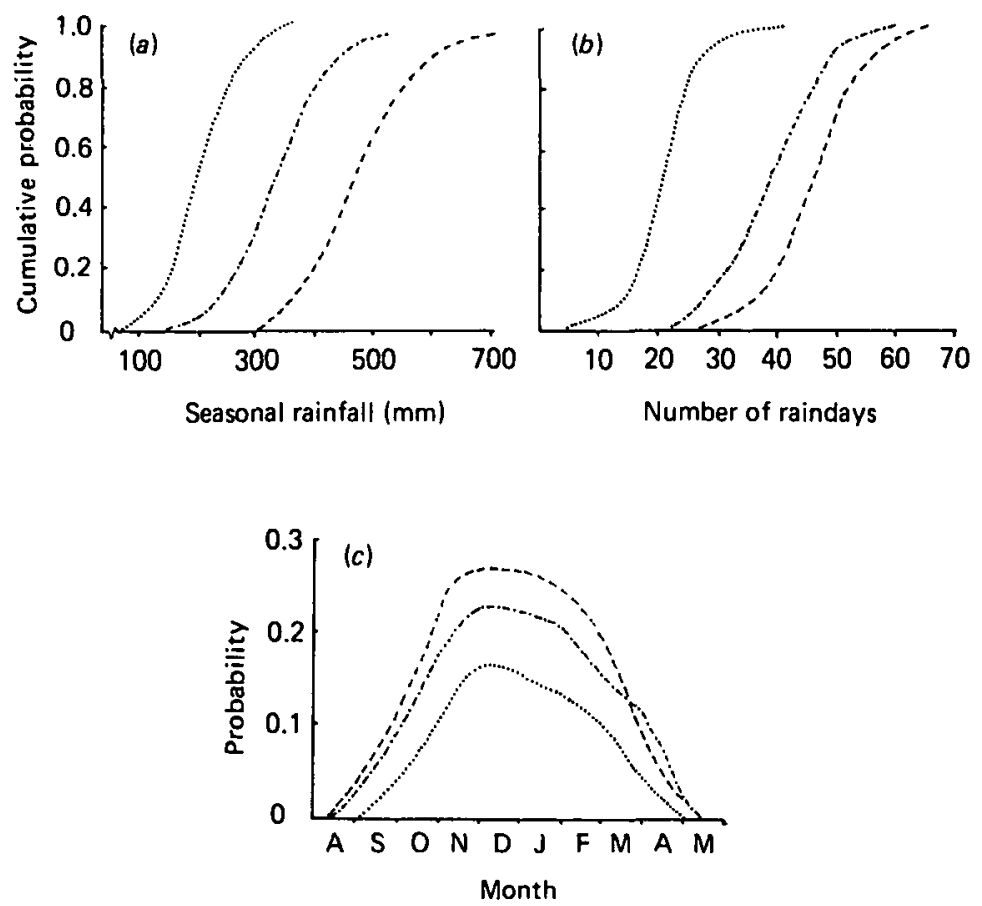

Fig. 2. Variability associated with rainfall at Jindiress (- - ), Aleppo (- - - - ) and Khanasser (....) in NW Syria: (a) cumulative probability of season rainfall totals; (b) cumulative probability of seasonal number of raindays; and (c) seasonal distribution of probability of rainfall events. 
Table 1. Mean monthly maximum and minimum air temperatures $\left({ }^{\circ} \mathrm{C}\right)$ at selected locations in the winter rainfall areas of west Asia and north Africa

$\begin{array}{llrrrrrrr}\text { Location } & & \text { Damascus } & \text { Amman } & \text { Baghdad } & \text { Tehran } & \text { Algiers } & \text { Rabat } & \text { Tripoli } \\ \text { Altitude (m) } & & 729 & 766 & 34 & 1191 & 60 & 75 & 20 \\ \text { Jan. } & & & & & & & & \\ & \text { Max. } & 12.3 & 12.5 & 15.8 & 9.4 & 15.0 & 17.0 & 17.0 \\ \text { Feb. } & \text { Min. } & 2.5 & 3.7 & 4.3 & -0.3 & 9.0 & 9.0 & 8.0 \\ & \text { Max. } & 14.1 & 13.7 & 18.7 & 11.0 & 16.0 & 18.0 & 18.0 \\ \text { Mar. } & \text { Min. } & 3.3 & 4.3 & 5.9 & 0.6 & 9.0 & 9.0 & 9.0 \\ & \text { Max. } & 17.8 & 17.6 & 22.7 & 15.8 & 17.0 & 19.0 & 20.0 \\ \text { April } & \text { Min. } & 5.2 & 6.2 & 9.6 & 4.0 & 11.0 & 10.0 & 10.0 \\ & \text { Max. } & 22.8 & 22.6 & 28.7 & 20.9 & 20.0 & 20.0 & 23.0 \\ \text { May } & \text { Min. } & 8.6 & 9.3 & 14.6 & 8.9 & 13.0 & 11.0 & 13.0 \\ \text { June } & \text { Max. } & 28.5 & 28.0 & 35.8 & 30.2 & 23.0 & 23.0 & 25.0 \\ & \text { Min. } & 12.6 & 13.4 & 20.0 & 15.7 & 15.0 & 14.0 & 16.0 \\ \text { July } & \text { Max. } & 33.6 & 31.0 & 41.0 & 34.2 & 27.0 & 26.0 & 29.0 \\ & \text { Min. } & 16.1 & 16.3 & 23.4 & 19.8 & 18.0 & 16.0 & 19.0 \\ \text { Aug. } & \text { Max. } & 35.8 & 32.1 & 43.4 & 36.6 & 28.0 & 26.0 & 30.0 \\ & \text { Min. } & 17.2 & 18.1 & 25.3 & 22.7 & 21.0 & 17.0 & 21.0 \\ \text { Sept. } & \text { Max. } & 36.1 & 32.8 & 43.3 & 36.3 & 29.0 & 27.0 & 31.0 \\ & \text { Min. } & 17.5 & 18.4 & 24.6 & 22.8 & 22.0 & 18.0 & 22.0 \\ \text { Oct. } & \text { Max. } & 32.4 & 30.9 & 39.8 & 31.0 & 27.0 & 26.0 & 30.0 \\ \text { Nov. } & \text { Min. } & 15.3 & 16.2 & 21.0 & 18.0 & 21.0 & 17.0 & 21.0 \\ \text { Dec. } & \text { Max. } & 27.1 & 27.5 & 33.4 & 23.2 & 23.0 & 24.0 & 28.0 \\ & \text { Min. } & 12.4 & 13.7 & 16.2 & 11.9 & 17.0 & 14.0 & 18.0 \\ & \text { Max. } & 19.8 & 21.0 & 24.6 & 16.8 & 19.0 & 20.0 & 23.0 \\ & \text { Min. } & 7.7 & 9.6 & 10.3 & 6.3 & 13.0 & 11.0 & 13.0 \\ & \text { Max. } & 14.0 & 14.8 & 17.7 & 11.9 & 16.0 & 17.0 & 18.0 \\ & \text { Min. } & 4.1 & 5.4 & 5.5 & 1.7 & 11.0 & 9.0 & 9.0\end{array}$

Source: Taha et al. (1981).

early summer months, winter sown crops are largely dependent on this stored soil moisture to complete their growth cycle.

The soils

The soils of the region are diverse, and 21 of the major soil groups recognized on the FAO/Unesco soil map of the world are found in west Asia and north Africa (FAO, 1978, 1979). The distribution and land use capability of these soils have been summarized by Kassam (1981). Seven major soil groups account for $86 \%$ of the $125 \times 10^{6}$ ha of rainfed agricultural land receiving between 200 and $600 \mathrm{~mm}$ year $^{-1}$ mean rainfall (Table 2). Calcareous soils, formed from limestone residuum, predominate in the region with very variable texture, depth, slope and stoniness.

Calcium carbonate plays an important role in the chemistry of soils because of its direct influence on soil $\mathrm{pH}$. The generally high $\mathrm{pH}$ of these soils decreases the availability of micronutrients such as iron, manganese, copper and zinc and responses to application of micronutrients are frequently observed under irrigation. Responses are less common in rainfed agriculture, although they have been reported (Haddad et al., 1979) and are more thoroughly reviewed else- 

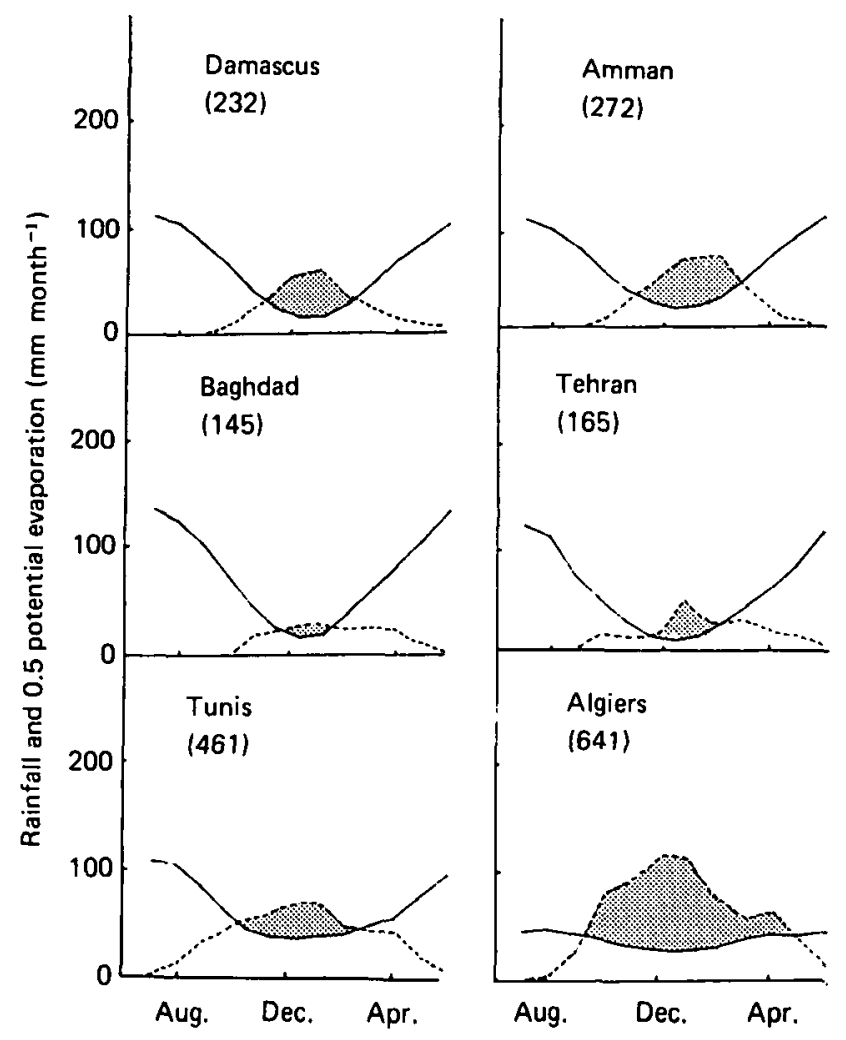

Fig. 3. Monthly mean rainfall (-..) and 0.5 potential evaporation (-) at six locations in west Asia and north Africa. Shaded areas are periods of potential soil moisture recharge and figures in parenthesis are mean annual rainfall. Source: Sivakumar and Huda, 1983.

where (El-Fauly, 1983). Calcium carbonate also has a pronounced effect on the availability of phosphorus because of the formation of insoluble or slowly soluble calcium phosphate salts (Harmsen, 1984b). In general, available phosphate levels are low when fertilizer is not applied. For instance, Harmsen (1984a) noted that over $85 \%$ of farmers' fields sampled in the dryland areas of northern Syria were chronically deficient in phosphate, and Matar (1986) showed that applied phosphate fertilizer was rapidly fixed resulting in an effective 'half life' of available fertilizer phosphorus of between five and ten months, fixation rates increasing with rainfall. These studies suggested that, depending on rate of application of phosphate and soil conditions, residual phosphate responses could be expected for up to 50 months after application at drier locations. Such residual effects have been commonly observed in NW Syria (Harmsen et al., 1983) and may be expected throughout the region.

Secondary deposition of calcium carbonate at the long-term average depth of rainfall penetration occurs in many soils, and can occasionally restrict moisture and root penetration. However, in most cases such secondary depositions are soft and friable in nature.

Organic matter levels are generally low and in some soils, particularly silts 
Table 2. Major soil groups in regions of north Africa and west Asia receiving between 200-600 $\mathrm{mm}$ annual rainfall

\section{Soil group}

Vertisols: Soils which, after the upper $20 \mathrm{~cm}$, are mixed and have more than $30 \%$ clay in all horizons to at least $50 \mathrm{~cm}$ depth. Characterized by cracks at least $1 \mathrm{~cm}$ wide to depths of $50 \mathrm{~cm}$ when dry, gilgai micro relief and slickensides at depth

Xerosols: Soils occurring under an arid moisture regime, having a weak $\mathrm{A}$ horizon and lacking the diagnostic characteristics of vertisols

Cambisols: Soils having a wide range of base status with their $A$ and $B$ horizons formed directly from the underlying parent material. Lacking the diagnostic characteristics of vertisols

Luvisols: Soils with a wide range of base status with A and B horizons characterized by clay translocation. Lacking the diagnostic characteristics of vertisols

Yermosols: Soils occurring under an aridic moisture regime with a weak $\mathrm{A}$ horizon and characterized by a gypsic horizon

Lithosols: Soils which are limited in depth by continuous coherent hard rock within $10 \mathrm{~cm}$ of soil surface

Regosols: Soils which are limited in depth by colluvial parent material within $10 \mathrm{~cm}$ of soil surface

\begin{tabular}{|c|c|c|}
\hline \multicolumn{3}{|c|}{ Area $\left(10^{6} \mathrm{ha}\right) \dagger$} \\
\hline N. Africa & W. Asia & Total \\
\hline 1.2 & 4.1 & 5.3 \\
\hline 5.6 & 22.0 & 27.6 \\
\hline 7.0 & 10.2 & 17.2 \\
\hline 3.8 & 7.7 & 11.5 \\
\hline 3.1 & 6.3 & 9.4 \\
\hline 5.4 & 20.6 & 26.0 \\
\hline 2.4 & 7.9 & 10.3 \\
\hline
\end{tabular}

† Area data from: Kassam (1981).

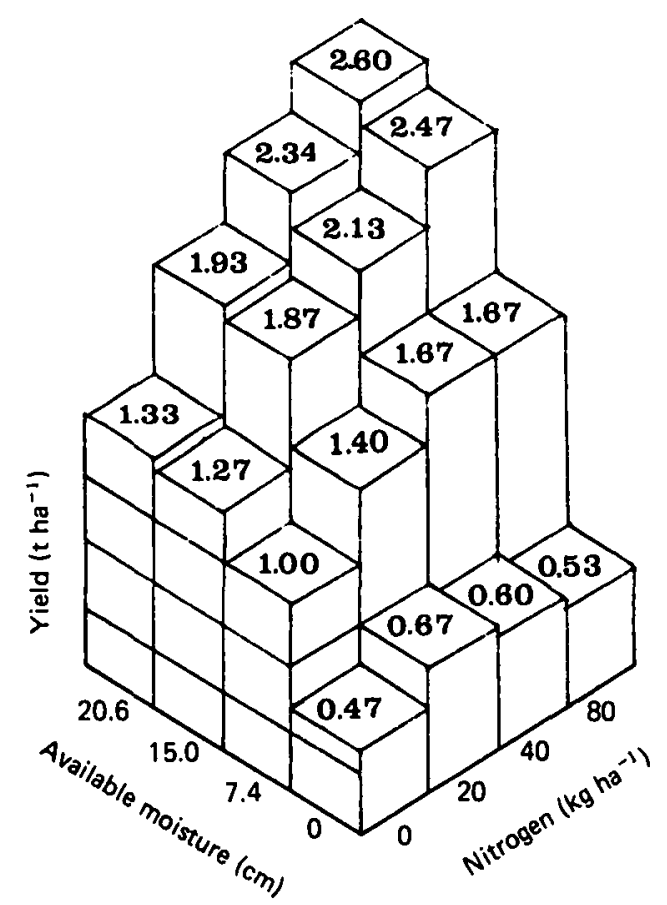

Fig. 4. The effect of crop available moisture on the grain yield reponse of wheat to nitrogen fertilizer. Source: Ramig and Rhoades, 1962. 
and sands, structural stability is poor. In such soils, surface capping by rainfall can cause serious problems in seedling emergence and surface runoff (Plate la). Ghanem et al. (1983) reported such problems as a serious constraint to production on the soils at Souihla, Morocco and Sabet and Harris (1986) have reported similar results for calcic Xerosols in Syria. Organic nitrogen levels are also low and nitrogen deficiency is widespread in the region (van Keulen, 1977). Many researchers have reported responses to nitrogen fertilizer (e.g. Harmsen, 1984c; Anderson, 1985b). Nitrogen reponses are closely related to amounts of rainfall, and tend to decrease with decreasing available moisture (Fig. 4). This dependence of crop response to nitrogen fertilizer on the availability of moisture has been well documented and recently reviewed by Vlek et al. (1981). Loss of nitrate from the rooting zone through deep leaching is not a common problem (ICARDA, 1983, p. 17) but under certain conditions volatilization of ammonia can give rise to considerable nitrogen losses in these calcareous soils (Vlek et al., 1981).

Soil depth is also variable. In a recent survey of wheat producers in NW Syria, Rassam and Tully (1986) observed that in $25 \%$ of farmers' fields, soils were less than $50 \mathrm{~cm}$ deep, and in only $58 \%$ was there more than one metre of soil. Another survey east of Aleppo revealed that $63 \%$ of annually sown rainfed land was less than $40 \mathrm{~cm}$ deep, only $20 \%$ being deeper than $80 \mathrm{~cm}$ (Tully, 1985). Both soil depth and soil texture are important in determining the maximum amount of water that can be stored during the winter months, which in turn will determine the effective length of the growing season. Smith and Harris (1981) demonstrated the effect of soil with different moisture holding capacities on the length of the growing season at Aleppo, Syria using computer simulation (Fig. 5). The effect of storage capacity was dependent on rainfall. In dry years the maximum water holding capacity was not utilized, thus there was little effect of this parameter on the length of the growing season. In wetter years, however, water holding capacity played an important role. A greater proportion of rainfall percolated to depth and was stored in soils of high capacity to be used later to extend the final stages of crop growth, whereas in soils of low water holding capacity, the extra moisture could not be stored within the rooting zone, and growing season length was little affected. It is presumably for this reason that many farmers in high rainfall wheat-growing areas sow barley (an earlier maturing crop) on shallow soils of low water holding capacity (Gibbon, 1981; Tully, 1985).

\section{Crops and crop rotations}

The principal crops grown in the region are cereals, mainly wheat and barley, but with small areas of rye, oats and triticale in some countries (Table 3 ). In Turkey, bread wheat predominates, but in the Arab countries most of the wheat is durum which forms the basis of the flat breads, bulgher and couscous which are the basis of local diets. Barley is grown almost entirely as livestock feed (both grain and straw) but is also a significant food crop in Morocco 


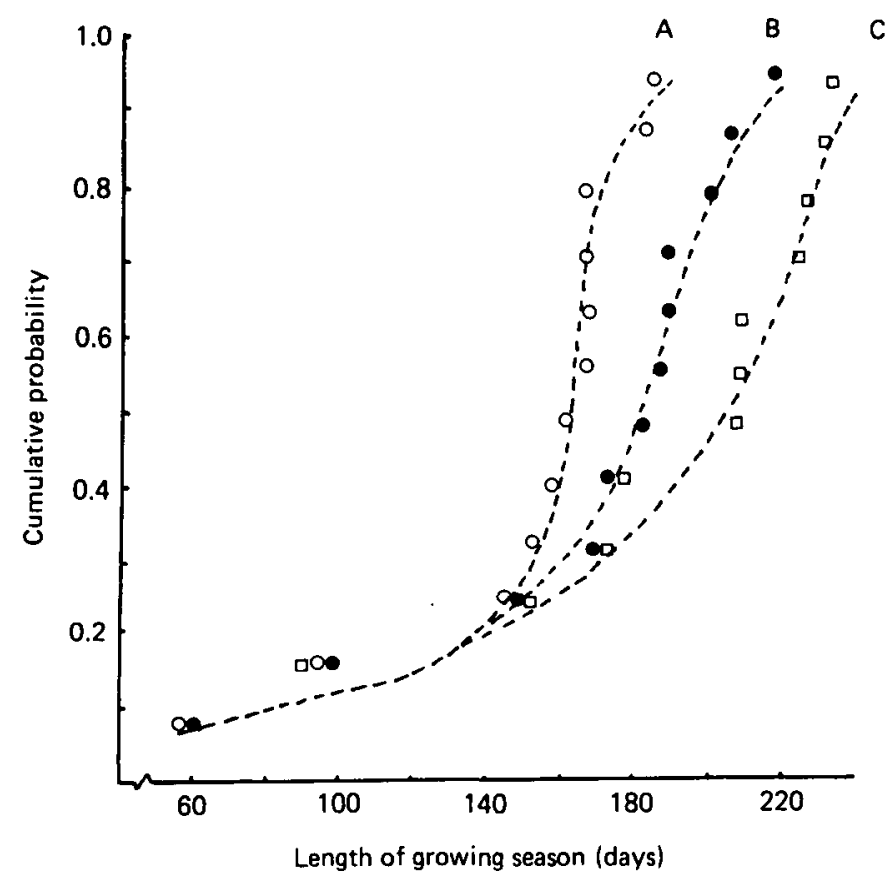

Fig. 5. Effect of soil water storage capacity (A: $76 \mathrm{~mm}, \mathrm{~B}: 150 \mathrm{~mm}, \mathrm{C}: 200 \mathrm{~mm}$ ) on the cumulative probability distribution of length of growing season at Aleppo, NW Syria.

Table 3. Land use in west Asia and north Africa in 1981/83 ( $\times 10^{3} \mathrm{ha}$ )

$\begin{array}{lrrrccc} & \text { Wheat } & \text { Barley } & \text { Pulses } & \begin{array}{c}\text { Other } \\ \text { arable crops }\end{array} & \begin{array}{c}\text { Permanent } \\ \text { crops }\end{array} & \begin{array}{c}\% \text { crops } \\ \text { rainfed }\end{array} \\ \text { Algeria } & 1741 & 880 & 122 & 4084 & 642 & 90 \\ \text { Libya } & 266 & 264 & 9 & 1199 & 315 & 90 \\ \text { Morocco } & 1770 & 2142 & 347 & 3010 & 430 & 94 \\ \text { Tunisia } & 809 & 490 & 144 & 1997 & 1420 & 97 \\ \text { Iraq } & 1187 & 958 & 46 & 2909 & 187 & 70 \\ \text { Jordan } & 104 & 52 & 16 & 185 & 34 & 91 \\ \text { Lebanon } & 18 & 5 & 10 & 207 & 108 & 76 \\ \text { Syria } & 1256 & 1485 & 201 & 2414 & 369 & 90 \\ \text { Cyprus } & 14 & 50 & 6 & 295 & 67 & 78 \\ \text { Turkey } & 9040 & 2951 & 909 & 12077 & 2787 & 93 \\ & & & & & & \end{array}$

Source: FAO (1984).

and Tunisia. In many countries, overgrazing has led to a decline in productivity of natural grazing lands whilst demand for animal products for urban consumption has increased. Thus within the last ten years the demand for and acreage sown to barley has increased at the expense of wheat. For instance, between 1974 and 1983 the area sown to barley in Syria increased from 960 to $1485 X$ $10^{3}$ ha, whilst wheat decreased from 1607 to $1256 \times 10^{3}$ ha. Similar trends have been observed in Algeria, Tunisa, Iraq and Morocco (FAO, 1984).

Food legumes, mainly faba bean, chickpea and lentils, are also grown but only occupy between 5 and $10 \%$ of the area planted to cereals (Table 3 ). Nevertheless, they largely meet local demand and are exported from Turkey, 
Syria, Tunisia and Morocco. Faba beans are commonly irrigated or limited to the wettest areas, whereas chickpea and lentils are grown in the medium rainfall areas of 300-600 mm mean annual rainfall. They are seldom grown in areas where low rainfall or soils of low water holding capacity limit moisture supply, presumably because of their sensitivity to moisture stress at flowering (Ketata et al., 1979; Newburg et al., 1982). Under such conditions, low and variable yields, combined with the high costs of both weeding and harvesting by hand, currently make production uneconomical (Tully, 1984).

Other rainfed crops are very diverse, and largely fall within the category of summer crops. These are grown in the higher rainfall areas (more than $350 \mathrm{~mm}$ ) on soils with a high moisture storage capacity. They are planted in spring after a winter fallow period and grow during the summer months on stored soil moisture. Such crops include watermelon, canteloupe, sesame, cotton, sunflower, sorghum and maize. As shown in Table 3, permanent crops are also a regular component of agriculture in this region, and include citrus, olives, vineyards, pomegranates and nuts. In the areas of higher potential rainfall such tree crops are a major source of income for many farmers (Plate 1b).

The most common crop rotation in the region is a two year sequence of cereal-fallow, although the management of the fallow varies considerably throughout the region. During the 1960s wheat researchers in the high central plateau of Turkey developed a technique of shallow cultivations in the fallow year, which under the prevailing cooler conditions both reduced weeds and increased moisture storage for the subsequent wheat crop. Coupled with early sowing, fertilizer use and high yielding varieties, this has led to a dramatic increase in wheat production in the last 15 years (Guler et al., 1979; Harison et al., 1982). A similar practice is also used in parts of Algeria and Tunisia (Benzaghou, 1979) although under the higher temperature conditions of north Africa the principal benefit of a cultivated fallow appears to be in controlling weeds rather than conserving moisture.

The more common practice, especially for farmers with small holdings, is an uncultivated fallow, particularly in north Africa. The weeds and volunteer crops on the fallow land provide cheap and valuable livestock feed in the winter and spring months (Plate 1c).

In many countries of the region work is underway to try and encourage forage legume production, using both annually sown and self-regenerating pastures, to replace the existing weedy fallows in the drier areas (Bakhtri, 1979; Loizides, 1979; Photiades, 1979). Currently, the relatively high production costs, compared to the 'free' weedy fallow and native pastures, are a severe constraint on the adoption of this practice by farmers (Tully, 1984). However, where native pastures are not available and weed infestation levels on fallows are low, annually sown forage legumes can economically replace the fallow, either as a crop for spring grazing or for harvesting at maturity and storage for subsequent use (Thomson et al., 1986).

In the higher rainfall areas, food legumes and summer crops are often grown 
in the place of fallow, particularly on the deeper soils, either in a two year rotation with cereals, or less frequently in a three year rotation including cereal, legumes and summer crops.

\section{Field operations}

The cultivation of rainfed field crops is relatively simple, and operations are mechanized to varying extents. Seedbed preparation is nearly all carried out by tractors and may be done just before planting in autumn, during summer or even the previous spring. A wide variety of implements is used, including disc ploughs, mouldboard ploughs, spike tooth harrows, disc harrows and ducks-foot cultivators. In some cases, particularly on poor stony soils, no seedbed preparation is carried out and only a seed covering operation is performed.

Most sowing takes place between October and December, depending on the crop, region and the timing of the onset of the rainy season. Seed is, in most cases, broadcast by hand which remains a cheap and relatively rapid operation (Plate $1 \mathrm{~d}$ and e). Drills have come into use in certain areas but are not normal. Phosphate fertilizer, if applied, may be broadcast at the same time as the seed, but in many instances is broadcast and incorporated into the soil one or two months in advance of seeding. Several studies (e.g. Matar, 1986) have demonstrated greatly increased responses to phosphate when it is placed with the seed at sowing. Starter doses of nitrogen are often applied with the seed, but most farmers top-dress in early spring when the amount applied can be adjusted according to the rainfall received (Rassam and Tully, 1986). The seed is covered by a variety of implements, often the same as those used for seedbed preparation, but ducks-foot cultivators and disc harrows are most common.

Herbicides (most usually 2, 4-D) are frequently used on cereals, but livestock owners often weed by hand and use the weeds as forage. Currently all food legume crops are weeded by hand, and farmers will of ten delay sowing to allow weeds to germinate so that they are then killed by the pre-sowing tillage operation.

Harvesting of cereals is extensively mechanized; however, hand harvesting continues to play a role in areas where equipment is not available, where the soils are too stony or uneven or where maximum straw yield is required as animal feed. When expected yields are very low and the crop is uneconomic to harvest it is often grazed as a mature standing crop. Legumes, on the other hand, are almost entirely harvested by hand mainly because harvesting equipment suitable for local conditions has not yet been developed (Plate 1f).

\section{Livestock}

The close integration of livestock in the farming systems of west Asia and north Africa plays a key role in determining the current crop production strategy of the majority of farmers in the region, and has been reviewed elsewhere (Photiades, 1979; Smith, 1979; Tully, 1986). It is not intended to discuss livestock production in detail, but certain aspects of the inter-relation 


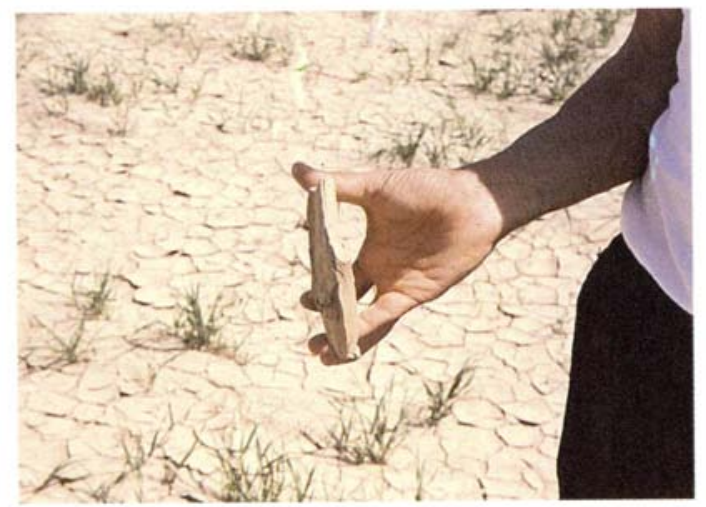

la. Soil capping on silty soils of low structural stability can cause problems in scedling emergence and with surface runoff.

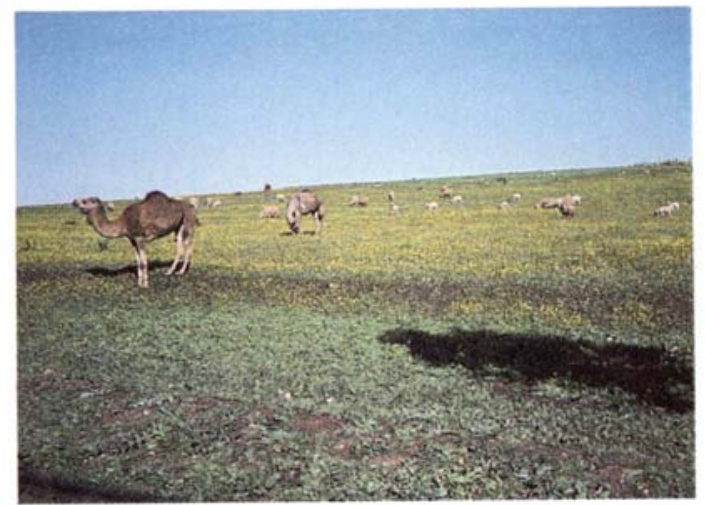

1c. Weeds and volunteer crops on fallow land are a valuable source of feed during winter and early spring, particularly in north Africa.

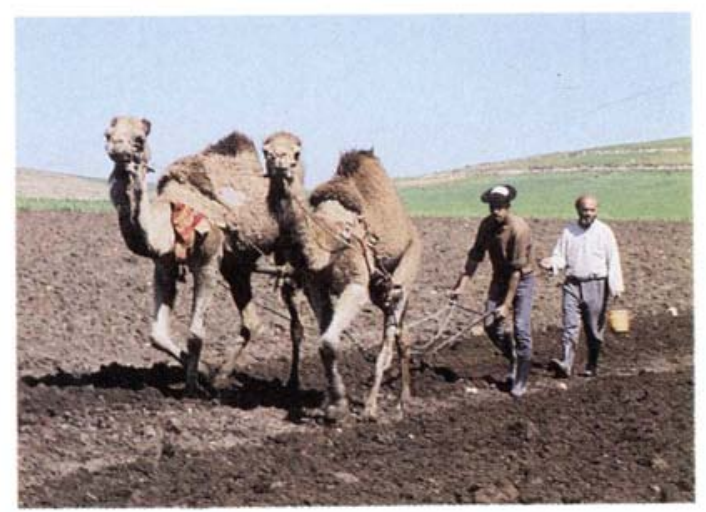

le. Large-seeded summer crops, such as maize, are still mostly sown by hand in Morocco and other countries of the region.

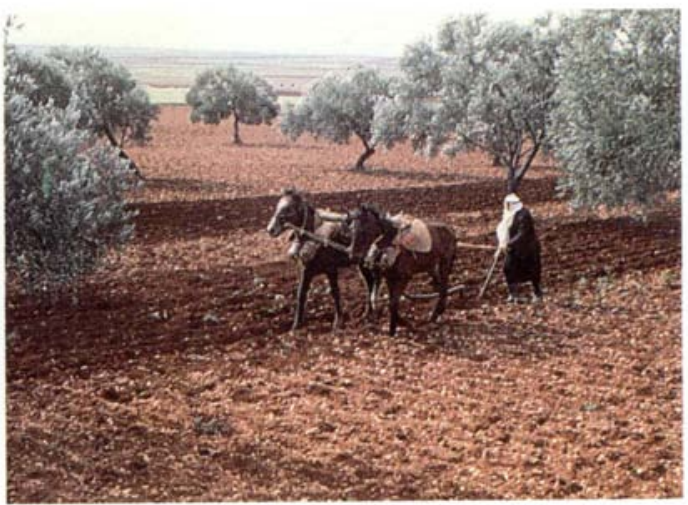

lb. In higher potential rainfall areas, tree crops such as olives are a major source of income for many farmers. Most olive groves are kept free from weeds and intercropping is seldom practised.

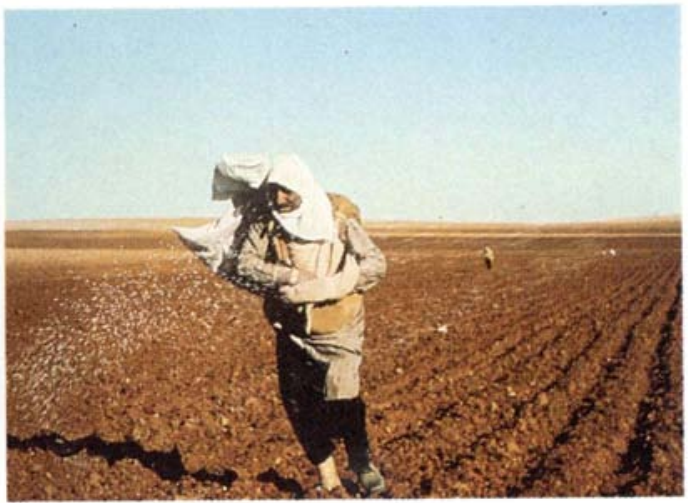

Id. Throughout the region small-grain cereals and legumes are usually broadcast by hand, which remains a cheap and relatively rapid operation.

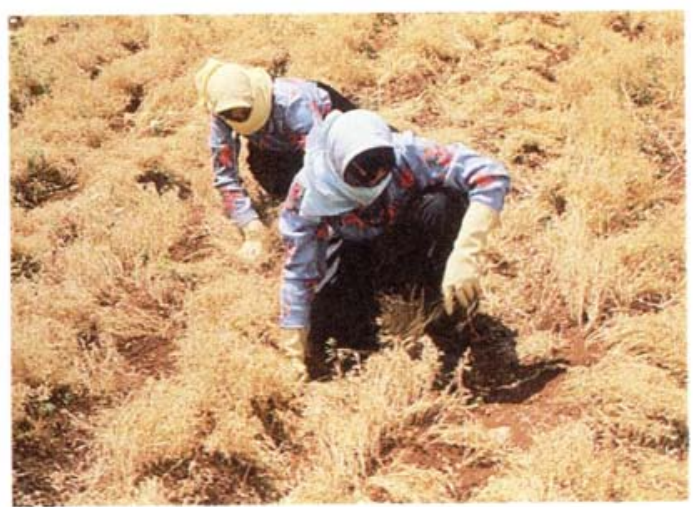

1f. Lentils, and other legumes such as chickpeas and faba beans, are almost entirely harvested by hand throughout the region for lack of suitable equipment. 


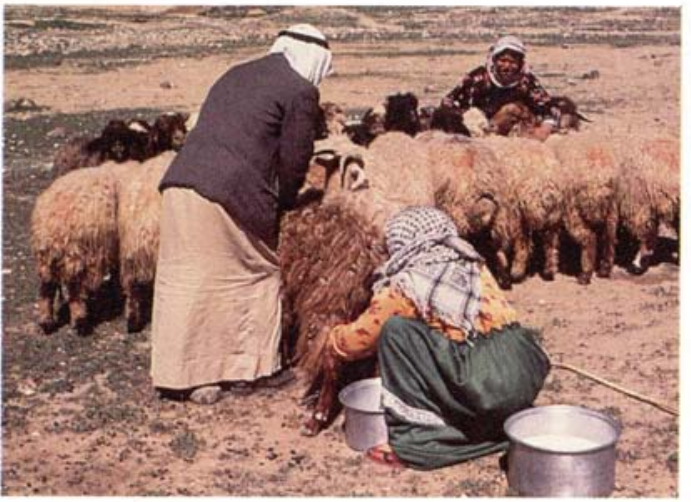

2a. Livestock in the region are chiefly valued as a source of milk and dairy products, with meat and wool sales being less important sources of income.

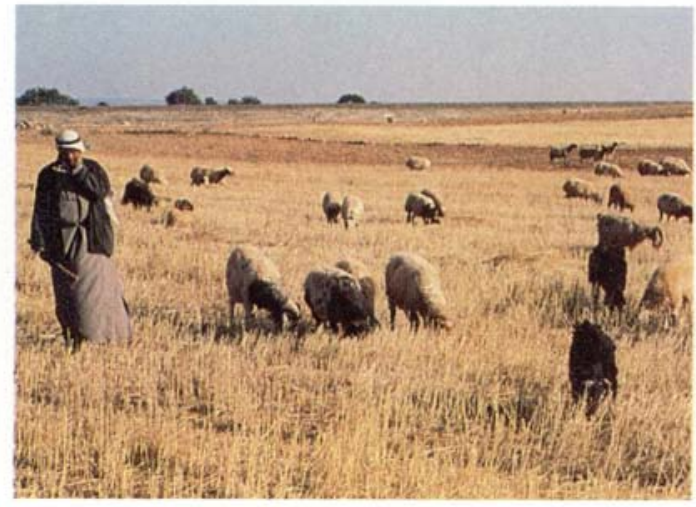

2c. After harvest, crop stubbles and residues are used to feed animals throughout the summer and early autumn months.

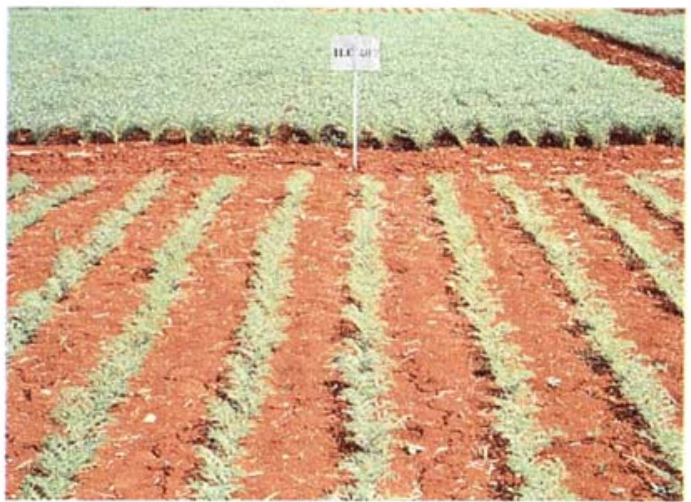

2e. In Syria, winter-sown chickpea (background) achieved more rapid canopy closure, reducing soil evaporative losses and increasing crop transpiration compared with traditional spring-sown crops (foreground).

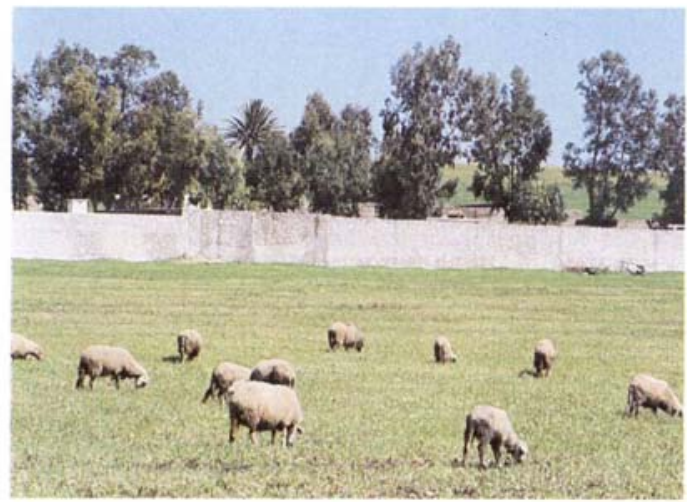

2b. In north Africa and west Asia farmers frequently graze cereal crops during early growth when natural pastures are unproductive or unavailable.

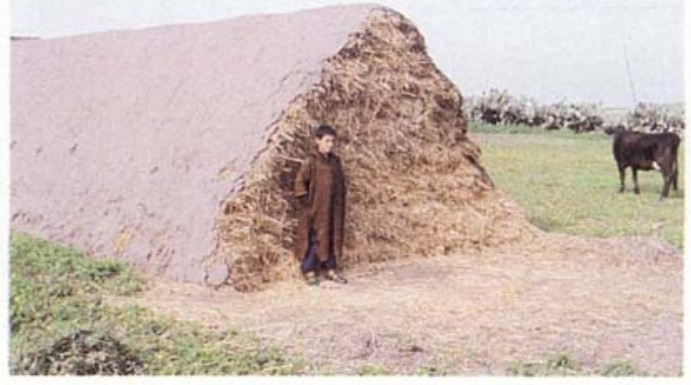

2d. In Morocco, and elsewhere in the region, surplus wheat and barley straw is frequently stored for up to two years for animal feed.

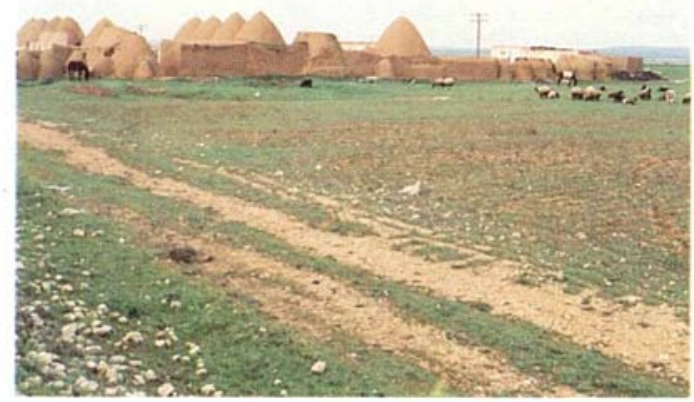

2f. In the barley producing areas of NW Syria, farms tend to be small and family operated. 


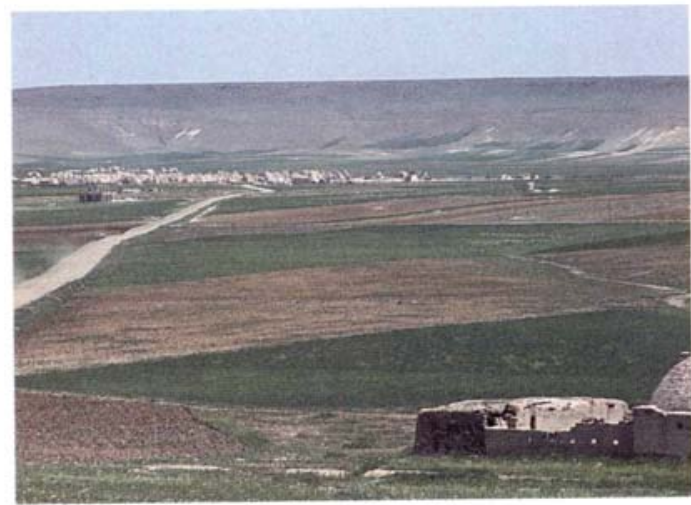

3a. A view of Bueda near Breda in NW Syria showing the predominant barley/fallow rotation and the hillsides in the background which are used as communal grazing areas for livestock.

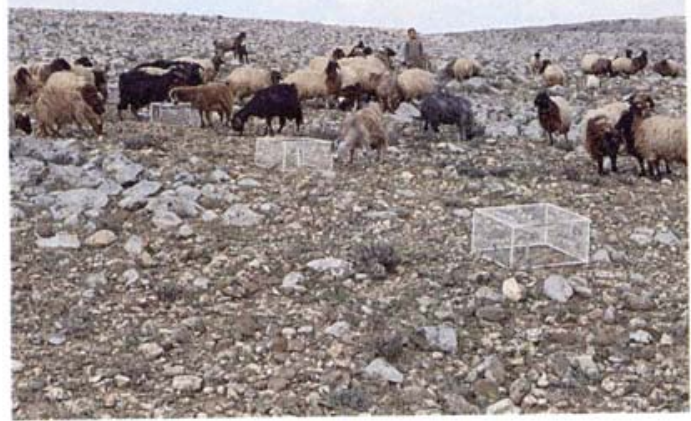

3c. In drought years, communal grazing areas are unproductive and farmers are forced to graze their barley crops.

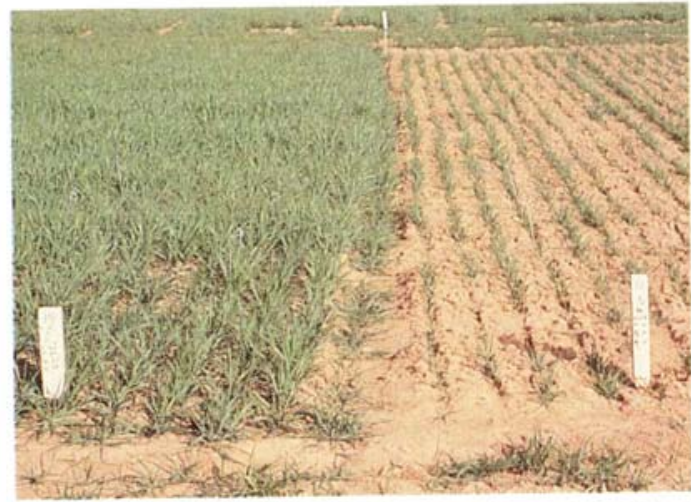

3e. In the P-deficient soils of NW Syria, banded phosphate fertilizer (on left) promotes rapid carly growth of barley, reducing soil evaporative losses and increasing crop transpiration compared with control treatment (on right).

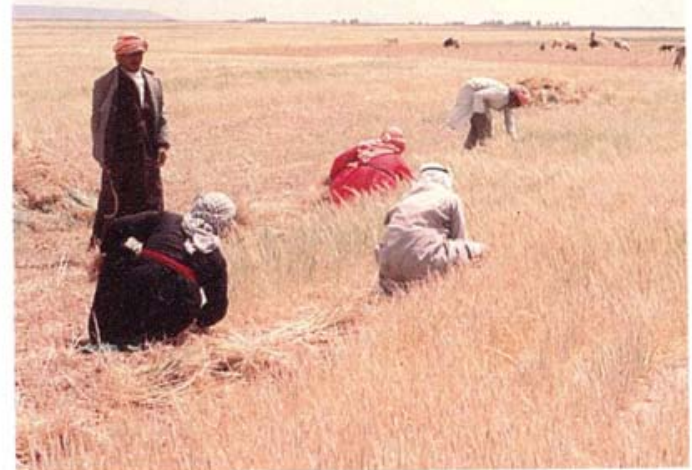

3b. When yields are low, barley is often harvested by hand to maximize straw yields.

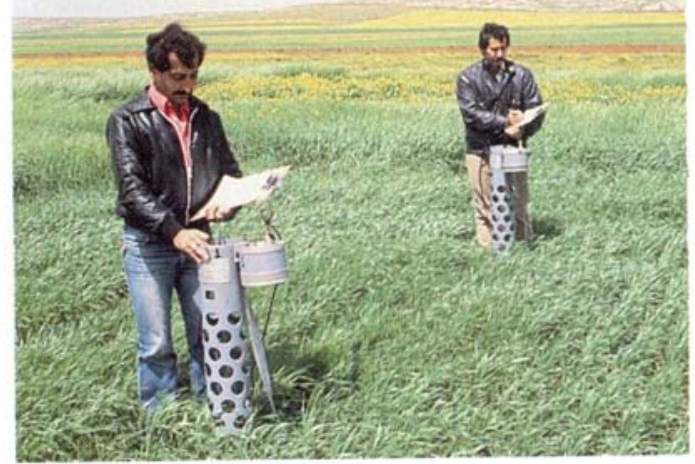

3d. Detailed crop water use studies using neutron probes have been undertaken in NW Syria to assess the effect of phosphorus and nitrogen fertilizer on the water balance of the system.

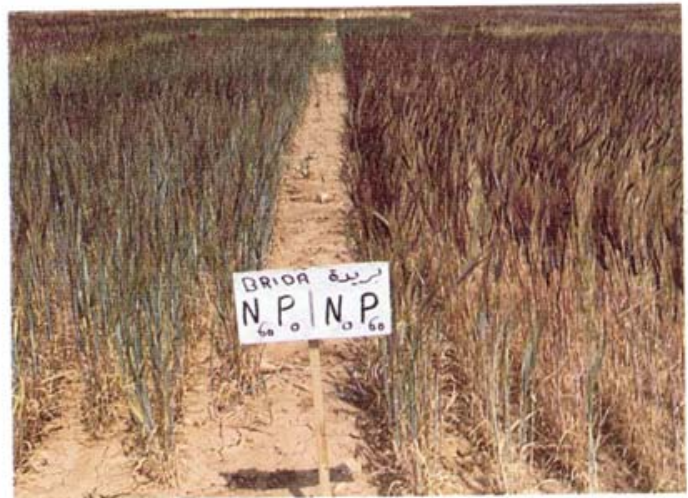

3f. In a Soils Directorate/ICARDA cooperative on-farm trial, phosphate fertilizer applied to barley (Arabic Aswad) on the right increased yields and advanced maturity of the crop. 
Table 4. Livestock production in west Asia and north A frica in 1981/83

\begin{tabular}{|c|c|c|c|c|c|c|c|c|}
\hline & & mals (10 & & & $(1000$ & & Milk & 0 ton) \\
\hline & Sheep & Goats & Cattle & Sheep & Goats & Cattle & Shp/Gt & Cow \\
\hline Algeria & 13730 & 2763 & 1389 & 68 & 13 & 43 & 316 & 530 \\
\hline Libya & 4598 & 1412 & 175 & 53 & 2 & 29 & 54 & 64 \\
\hline Morocco & 14913 & 6240 & 3047 & 59 & 23 & 116 & 50 & 790 \\
\hline Tunisia & 4980 & 875 & 572 & 24 & 3 & 34 & 30 & 226 \\
\hline Iraq & 11883 & 3767 & 3033 & 43 & 15 & 55 & 234 & 1075 \\
\hline & 1021 & 540 & 37 & 6 & 7 & 2 & 40 & 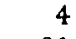 \\
\hline Lebanon & 143 & 442 & 53 & 11 & 4 & 9 & 56 & 91 \\
\hline Syria & 10969 & 1103 & 799 & 88 & 7 & 34 & 539 & 599 \\
\hline Cyprus & 518 & 360 & 43 & 6 & 4 & 4 & 64 & 51 \\
\hline Turkey & 49288 & 18727 & 17003 & 294 & 108 & 211 & 1865 & 3613 \\
\hline
\end{tabular}

Source: FAO (1984).

between crop and livestock production have important implications in improving the water use efficiency of crop production.

Sheep, goats and cattle are the most important livestock species in the region (Table 4), and the majority of sheep and goats are found in the steppe or drier crop production areas whilst cattle are more commonly found in the wetter or irrigated areas and in dairies near cities. They are a major source of income, particularly on the smaller farms (Campbell et al., 1977; Papachristodoulou, 1979 ) and act as a financial buffer against yearly fluctuations in crop production associated with the variability of rainfall. Livestock are valued chiefly as a source of milk and dairy products which are an important source of calories and protein in the local diets (Miladi, 1983; Mokbel, 1985) whereas meat consumption is more limited (Plate 2a). The sale of wool constitutes a third, but less important, source of income.

Feeding of livestock follows a yearly cycle. Fresh fodder is first available in late winter or early spring and remains available until the beginning of summer. Weedy fallow lands and grazing areas are at their most productive during the spring months, the period when lambs are weaned and ewes produce most milk. Such grazing is supplemented by weeds pulled from crops, and often weed control with herbicides will be delayed or even omitted in order to increase this supply of fodder (Newburg et al., 1982; Rassam and Tully, 1986). Cereal crops may also be grazed during early growth, a practice which some farmers claim is beneficial to yield through improved tillering and reduced lodging (Plate 2b). However, in the dry barley-producing zones of northern Syria, this practice has been shown to reduce yields considerably (ICARDA, 1984, p. 48). During this period, income from stock sales and dairy produce is at a peak, sustaining many farmers until the crop harvest.

After harvest, crop stubbles and residues from wheat, barley, legumes and summer crops are used to feed the animals throughout the summer and early autumn months. In years of low productivity standing crops of cereals, uneconomic to harvest, are also grazed. In general, all crop residues are used as 
animal feed and in many instances the value of the straw may equal or exceed the monetary value of the grain (Plate $2 c$ and $d$ ).

Livestock feeding is most difficult in late autumn and early winter. With the onset of the rains, early winter grazing may be good but it is unreliable, being dependent on both rainfall and temperature. In many areas supplementary feeding, largely of barley grain and straw, is required to sustain the flocks until the spring months when natural grazing is once again more assured.

Urban demand for livestock products is increasing as are livestock numbers. Given the increasing importance of livestock within the region, it is clear that certain strategies for improving water use efficiency of food crop production, such as improved fallow management, weed control through herbicide use, or the introduction of new crop species with less, or less palatable, straw could all encounter obstacles in farmer adoption. Strategies aimed at increasing food crop production must ensure that vital sources of animal feed are not jeopardized.

\section{Farm size}

In all countries of the region, the majority of farmers cultivate areas of less than 10 ha (Table 5), such holdings occupying between 16 and $67 \%$ of the arable land. At the other extreme, farms of over 50 ha are relatively few but occupy a substantial area, while holdings of between 10 and 50 ha form a sizeable minority of farms and land area in all countries. The implications of farm size on crop and animal production and household strategies have been discussed by many authors, and recently reviewed by Tully (1986). In summary, west Asia and north Africa are marked by a duality between large farms, often state owned, and small private holdings. The larger farms are usually involved in commercial crop production, while small farms are more of ten subsistence oriented. Farmers with small holdings invest more in livestock which may contribute up to half of their income; this is supplemented with off-farm labour

\section{Table 5. Distribution of land holdings in west Asia and north Africa}

\begin{tabular}{|c|c|c|c|}
\hline \multicolumn{4}{|c|}{ Farm size (ha) } \\
\hline $0-5$ & $5-10$ & $10-50 \quad 50-100$ & $100+$ \\
\hline
\end{tabular}

\begin{tabular}{|c|c|c|c|c|}
\hline \multicolumn{5}{|c|}{ Farm size (ha) } \\
\hline $0-5$ & $5-10$ & $10-50$ & $50-100$ & $100+$ \\
\hline
\end{tabular}

\begin{tabular}{llrrrrc} 
Iraq $\dagger$ & 39.7 & 25.4 & 32.6 & 1.2 & & 1.2 \\
Jordan $\dagger$ & 63.5 & 17.0 & 17.4 & 1.4 & & 0.7 \\
Lebanon $\ddagger$ & 90 & \multicolumn{1}{c}{6} & \multicolumn{1}{c}{3} & - & 0.5 & - \\
Syria $\dagger$ & 56.4 & 17.4 & 23.5 & 1.8 & & 0.9 \\
Cyprus & 89.8 & 7.8 & 2.2 & - & 0.3 & - \\
Turkey & 72.9 & 19.2 & 7.0 & 0.6 & & 0.2 \\
Algeria $\dagger$ & 61.6 & 17.6 & 18.9 & 1.4 & & 0.5 \\
Libya $\dagger$ & 46.8 & 20.6 & 29.4 & 2.4 & & 0.8 \\
Morocco $\dagger$ & 73.7 & 14.9 & 10.7 & 0.5 & & 0.2 \\
Tunisia $\dagger$ & 42.1 & 21.3 & 32.3 & 3.0 & & 1.2
\end{tabular}

$\begin{array}{rllrrr}6.9 & 12.4 & 39.7 & 6.3 & 34.8 \\ 13.6 & 14.6 & 41.9 & 11.6 & 18.3 \\ 44 & 16 & 25 & - & 15 & - \\ 10.7 & 11.3 & 45.7 & 11.1 & & 21.1 \\ 37.0 & 20.0 & 18.0 & - & 24.9 & - \\ 26.6 & 39.5 & 19.8 & 8.8 & 5.3 \\ 14.2 & 15.7 & 47.0 & 11.8 & 11.4 \\ 6.5 & 9.8 & 40.8 & 10.8 & 32.1 \\ 24.5 & 20.7 & 37.7 & 7.2 & 10.0 \\ 6.6 & 10.5 & 43.9 & 13.3 & 25.7\end{array}$

Source: † AOAD (1984); ‡ Saab (1973); § Karouzis (1980); ๆ Ulusan (1980). 
activities. Much of their produce is used for home consumption, particularly durum wheat, dairy products and pulses.

In the past it was thought that small farm size might prove an obstacle to improved production techniques, and projects have often focussed on larger farms for this reason (Hogan et al., 1984). However, recent surveys in Turkey, Syria and Tunisia have shown that many farmers with holdings of less than 10 ha are increasingly using fertilizer, herbicide and new cultivars, and have access to tractors and combine harvesters through custom services (Aricanli and Somel, 1979; ICARDA, 1985, p. 55; Rassam and Tully, 1986). Currently there is a greater appreciation of equity issues and the importance of increasing the security of rural life, and as a result small farms are more often included in development programmes.

\section{CROP WATER USE AND WATER USE EFFICIENCY}

Within the last few decades, modern technology and agricultural research have led to discoveries which can enable farmers to overcome many of the constraints which previously limited their crop yields. Chemical fertilizers, new crop varieties, pesticides, herbicides and mechanization of farm operations can all assist the farmer in both increasing and stabilizing his production. However, in the rainfed farming systems of the Mediterranean region, the major constraint of low and erratic rainfall remains the one factor over which the farmer can exert no influence. Within this context the agricultural scientist seeks ways in which new technology can be incorporated into the existing farming systems to make maximum use of the moisture available for crop growth.

In testing such innovations under limited moisture conditions, agronomists frequently evaluate crop performance in terms of water use efficiency (WUE) written as:

$$
\text { WUE }=\frac{\text { Yield per unit area }}{\text { Water used to produce yield }}
$$

The yield may be expressed solely in terms of grain yield but, as already indicated, crop residues are important in Mediterranean regions as feedstuff so that in this context, yield is better expressed as the above-ground dry matter. The WUE equation ignores the root system although it may form about $20 \%$ of the total mass of a barley crop at harvest in this environment when no fertilizers are applied (Gregory et al., 1984). The equation can be expanded to provide a more explicit format. The dry matter production (DM) can be written as the product of the total seasonal transpiration $(T)$ and the ratio of the dry matter produced to amount of water transpired (DM/T). DM/T is sometimes called the transpiration efficiency:

$$
\mathrm{DM}=\mathrm{T}(\mathrm{DM} / \mathrm{T})
$$

Water is used by crop systems directly by transpiration (T) from the leaves 
and indirectly by evaporation $\left(E_{S}\right)$ from the soil surface beneath the crop canopy; this is commonly referred to as evapotranspiration. Equation 1 can therefore be written as:

$$
W U E=\frac{T(D M / T)}{T+E_{S}}
$$

which can be simplified to give (Cooper, 1983):

$$
\text { WUE }=\frac{\mathrm{DM} / \mathrm{T}}{1+\mathrm{E}_{\mathrm{S}} / \mathrm{T}}
$$

This equation is a more useful expression of the relation between growth and water use than Equation 1 because it highlights the only possible ways in which the WUE of dry matter production can be increased. First, the transpiration efficiency might be improved although, as we shall show later, the scope for this is limited and, for any particular crop, depends on the atmospheric saturation deficit. Second, if the water supply is limited, $\mathrm{T}$ might be increased relative to $E_{S}$. Finally, increasing the total amount of water used might result in more growth provided it resulted in increased $\mathrm{T}$ rather than simply increasing $\mathrm{E}_{\mathbf{S}}$. These three possible routes to increased crop growth will now be reviewed in relation to the Mediterranean environment.

\section{Factors affecting transpiration efficiency}

Recent advances in our understanding of the physical and physiological processes underlying crop growth and water use mean that the transpiration efficiency of different crops can now be quantified. When the gas exchange of individual leaves is examined, transpiration $\left(T_{L}\right)$ and carbon fixation $\left(N_{L}\right)$ can be described in terms of the vapour pressure gradient, the difference in $\mathrm{CO}_{2}$ concentration between the intercellular spaces and the external air, and the resistances to diffusion resulting from stomata $\left(r_{s}\right)$ and the leaf boundary layer $\left(r_{a}\right)$ (Penman and Schofield, 1951; Bierhuizen and Slatyer, 1965):

$$
\begin{aligned}
& \mathrm{T}_{L}=\frac{e_{i}-e_{a}}{r_{s}+r_{a}} \\
& N_{L}=\frac{c_{a}-c_{i}}{r_{s}^{\prime}+r_{a}^{\prime}}
\end{aligned}
$$

where $e_{i}$ is the saturated water vapour pressure in the sub-stomatal cavity at leaf temperature, $e_{a}$ the vapour pressure in the external air, and $c_{a}$ and $c_{i}$ the concentrations of $\mathrm{CO}_{2}$ in the ambient air and intercellular spaces, respectively. The prime notation on the resistance terms is to distinguish between resistances to water vapour $\left(r_{s}\right.$ and $\left.r_{a}\right)$ and resistances to $\mathrm{CO}_{2}\left(r_{s}^{\prime}\right.$ and $\left.r_{a}^{\prime}\right)$. It follows that the ratio of carbon fixation to transpiration can be written as:

$$
\frac{N_{L}}{T_{L}}=\frac{\left(c_{a}-c_{i}\right)\left(r_{s}+r_{a}\right)}{\left(e_{i}-e_{a}\right)\left(r_{s}^{\prime}+r_{a}^{\prime}\right)}
$$


This expression can be simplified in three ways. First, the stomatal and boundary layer resistances to both $\mathrm{CO}_{2}$ and water vapour are related to the diffusion coefficients of the two gases, which are approximately inversely proportional to the square roots of their molecular weights. This means that the ratio of $r_{s}+r_{a}$ to $r_{s}^{\prime}+r_{a}^{\prime}$ is approximately constant, with a value of 1.6. Second, for a range of conditions, the value of $\mathrm{c}_{\mathrm{i}} / \mathrm{c}_{\mathrm{a}}$ is almost constant depending upon the species of plant (Goudriaan and van Laar, 1978; Wong et al., 1979). Finally, because the daily average temperature of a leaf is frequently close to the mean air temperature, $e_{i}$ can be approximated by the saturation vapour pressure of the air, $e_{s}$. Making these simplifications and further assuming that, in carbon fixation, crops $(\mathrm{N})$ and individual leaves $\left(\mathrm{N}_{\mathrm{L}}\right)$ behave similarly, Equation 7 can then be written as:

$$
\frac{\mathrm{N}}{\mathrm{T}}=\frac{\mathrm{k}}{\mathrm{e}_{\mathrm{s}}-\mathrm{e}_{\mathrm{a}}}
$$

where $e_{s}-e_{a}$ is the daily mean saturation deficit of the air weighted only for the periods of transpiration, and $\mathrm{k}$ is a crop specific constant (Bierhuizen and Slatyer, 1965; Tanner and Sinclair, 1983). This equation shows that there are only limited possibilities for increasing the ratio of carbon fixed to water transpired and hence the transpiration efficiency (DM/T) of a crop.

One way of increasing $N / T$ is to decrease the value of $c_{i} / c_{a}$. Measurements show that plants such as maize and sorghum $\left(\mathrm{C}_{4}\right.$ plants $)$ can maintain $c_{i}$ at a lower concentration (about 100 to $150 \mathrm{ppm}$ ) than $C_{3}$ plants such as barley and legumes (about 220 to $260 \mathrm{ppm}$ ) (Pearcy and Ehleringer, 1984). Increased transpiration efficiency might therefore be attained by selection of cultivars that maintain lower values of $c_{i}$. However, Mediterranean climates with their cool winters are generally unsuitable for the growth of $\mathrm{C}_{4}$ crops and whilst it may be possible in the long term to change the leaf morphology and biochemistry of $\mathrm{C}_{3}$ plants to reduce $\mathrm{c}_{\mathrm{i}}$, this is not immediately likely. However, Farquhar and Richards (1984) have developed a technique that demonstrates clear differences in the ratio $c_{i} / c_{a}$ between wheat genotypes, and this may be a useful screening technique for improved water use efficiency in breeding programmes.

The most probable way of increasing $\mathrm{N} / \mathrm{T}$ in the short-term is to maximize carbon fixation when $e_{s}-e_{a}$ is small. $N / T$ will always be higher in humid than in arid regions so that crops in temperate regions will normally use less water than the same crops growing in arid regions to produce the same dry matter. For example, studies at Rothamsted in England showed that in the hot, dry summer of 1976 , the transpiration efficiency of barley was about $30 \mathrm{~kg} \mathrm{ha}^{-1}$ $\mathrm{mm}^{-1}$ compared with $43 \mathrm{~kg} \mathrm{ha}^{-1} \mathrm{~mm}^{-1}$ in the more typical summer of 1979 (Day et al., 1978; Gregory, 1984). The transpiration efficiency of barley grown in northern Syria is also typically $40-45 \mathrm{~kg} \mathrm{ha}^{-1} \mathrm{~mm}^{-1}$ (Cooper, 1983; Cooper et al., 1987). However, in Mediterranean climates where saturation deficits are low in winter and increase rapidly during early spring, transpiration efficiency 
will be greater during early growth than during grain-filling and crop production will be increased if early growth during the cool winter months is promoted. To illustrate this, Fischer (1981) showed that for wheat growing in southern Australia:

$$
\mathrm{DM} / \mathrm{T}\left(\mathrm{kg} \mathrm{ha}^{-1} \mathrm{~mm}^{-1}\right)=102-13.0 \mathrm{E}_{\mathrm{o}}+0.53 \mathrm{E}_{\mathrm{o}}{ }^{2}
$$

where $E_{o}$ is the open pan evaporation $\left(\mathrm{mm} \mathrm{d}^{-1}\right)$. In northern Syria, $E_{o}$ is typically $1 \mathrm{~mm} \mathrm{~d}^{-1}$ in winter rising to $5 \mathrm{~mm} \mathrm{~d}^{-1}$ in March and April, giving values of DM/T of 90 and $50 \mathrm{~kg} \mathrm{ha}^{-1} \mathrm{~mm}^{-1}$, respectively. Growth in the winter period is, then, 'cheap' in terms of water use, and management practices resulting in more winter growth should increase the overall transpiration efficiency of the crop. This might be achieved in practice by developing cultivars that are tolerant of or grow well under cool temperatures although the scope for this is probably limited.

Shortening the developmental time of the crop might also give higher transpiration efficiencies and higher yields provided that neither the amount of radiation intercepted nor the ability to extract soil water were significantly reduced. For example, several studies on the severely phosphorus-deficient soils in northern Syria have shown that applications of phosphate fertilizer to barley may reduce the time to physiological maturity by up to ten days depending on the season (Cooper, 1983; Shepherd et al., 1987). Cooper et al. (1987), in a study which included measurements of root dry matter production, showed that applications of fertilizer to two varieties of barley resulted in small but significant increases in transpiration efficiency (from $47 \mathrm{~kg} \mathrm{ha}^{-1} \mathrm{~mm}^{-1}$ to $54 \mathrm{~kg}$ $\mathrm{ha}^{-1} \mathrm{~mm}^{-1}$ averaged over two sites). In other studies where fertilizer has not had any noticeable effect on developmental rates, transpiration efficiency is unaffected by fertilizer. Kallsen et al. (1984) grew spring barley on sandy loams for two years in New Mexico with rates of nitrogen fertilizer ranging from 30 to $300 \mathrm{~kg} \mathrm{~N} \mathrm{ha}^{-1}$ and found that grain yield and transpiration were positively and linearly related irrespective of the rate of nitrogen application. Similarly, Walker and Richards (1985) induced large changes in tissue concentrations of potassium in alfalfa but found no change in transpiration efficiency until irradiance was low. They concluded that many of the claims for reduced transpiration efficiency at low nutrient levels may result from changes in assimilate partitioning between roots and shoots. Root growth as a proportion of total plant weight is frequently increased in soils of lower fertility (Brouwer, 1963; Russell, 1977) and root dry weight is rarely included in the dry matter measurements.

In summary, there seems little prospect at present of radically altering the transpiration efficiency of crop production in Mediterranean regions except by more rapid crop development and increased growth during the winter period when the saturation deficit is low. 


\section{Altering the balance of $T$ and $E_{s}$}

The principal ways in which evaporation from the soil surface might be reduced or the total water supply of the soil increased are summarized in Table 6. Water loss directly from the soil surface is a substantial component of the total water use of crops grown in Mediterranean environments. Cooper et al. (1983) showed that at two sites in northern Syria, $E_{S}$ was about 35 and $55 \%$ of the seasonal evapotranspiration for crops of wheat and barley, respectively, and Cooper et al. (1987) showed that in barley crops not supplied with fertilizer, $E_{S}$ may be $75 \%$ of evapotranspiration when crop growth is poor. Similarly, French and Schultz (1984) grew wheat on a range of soil types in South Australia and calculated that over an 11 year period, $\mathrm{E}_{\mathbf{S}}$ was on average about $33 \%$ of evapotranspiration. Their estimate of $110 \mathrm{~mm}$ loss by evaporation (obtained as the intercept on the $\mathrm{x}$-axis of a linear regression of dry matter yield against water use) was similar to that found in Western Australia (Tennant, 1981) and in the Pacific Northwest, USA (Papendick and Campbell, 1974) but considerably lower than the $124-172 \mathrm{~mm}$ range found by Cooper et al. (1987) in Syria. While the precise amounts of evaporation will vary from site to site and year to year, it is clear that there should be enormous potential for improving water use efficiency in such environments.

One means of reducing $E_{S}$ is to use a mulch of crop residues. However, because of the mixed cropping/livestock farming system practised in the dry areas of the Mediterranean region, crop residues are used as fodder and almost no mulching is currently practised. Residues may become available for mulching as yields increase through the adoption of other management techniques. Mulches have many effects but in terms of water conservation their principal effect is to reduce the rate of evaporation when the soil surface is damp (firststage drying) and thereby to extend the duration of this stage (Papendick and Campbell, 1974). However, if drying persists, the initial high rate of water loss from an unmulched soil is compensated for by the high resistance to water flow provided by dry soil, so that eventually the total water loss from the two systems is similar. Amounts of residue in the Pacific Northwest are typically $3 \mathrm{t} \mathrm{ha}^{-1}$ (compared with straw yields of between 1-2 $\mathrm{t} \mathrm{ha}^{-1}$ in northern Syria) and can result in substantial reductions in $\mathbf{E}_{\mathbf{S}}$ over a year. For example, Bristow et al. (1986) simulated the soil water balance under bare and residue-covered

Table 6. Agronomic practices available for either reducing evaporation from the soil surface or increasing the total soil water available for crops

Reducing evaporation from soil surface

Mulching

Application of fertilizer

Modifying plant population

Selecting varieties with rapid early growth

Early sowing
Increasing total water supply

Irrigation

Rain harvesting

Cultivation to reduce run-off and improve infiltration

Weed control

Fallowing

Application of fertilizer

Selecting varieties with extensive root systems 
soils in the Pacific Northwest and found a $36 \%$ reduction in the total $\mathrm{E}_{\mathrm{S}}$ (precipitation was $645 \mathrm{~mm}$ ) when soils were mulched. Mulching substantially reduced $E_{S}$ during the winter months when there were frequent rain showers but increased it during the summer months (see also van Doren and Allmaras, 1978).

Even if mulches were available in the Mediterranean region, it would be difficult to mulch fields where crops were growing using existing tillage equipment. However, since the growing crop canopy itself will shade the soil surface and thus reduce $E_{S}$, the most feasible ways of improving water use efficiency in Mediterranean agriculture currently revolve around increasing the early growth of the crop canopy and thus reducing $\mathrm{E}_{\mathrm{S}}$ during the winter when the soil surface is damp. The time of sowing is an important factor in determining water use efficiency and generally earlier sowing gives higher yields (assuming that rainfall persists and the crop does not emerge and then die). For example, French and Schultz (1984) studied the effect of sowing time in over 200 experiments in South Australia and found that for each week's delay in sowing after the optimum time, grain yield was reduced by $200-250 \mathrm{~kg} \mathrm{ha}^{-1}$. At one site (with $307 \mathrm{~mm}$ rainfall) where sowing was delayed by 2.5 months, dry matter yield was reduced from 12.2 to $4.6 \mathrm{t} \mathrm{ha}^{-1}$ and water use efficiency from 29.4 to $18.9 \mathrm{~kg} \mathrm{ha}^{-1} \mathrm{~mm}^{-1}$. In another example, Keatinge and Cooper (1983) showed that in NW Syria early planting of chickpea (in winter as opposed to the traditional time of spring) resulted in an increase in grain yield from 1.88 to $4.20 \mathrm{t} \mathrm{ha}^{-1}$ in a typical chickpea growing area (Plate 2e). Total evapotranspiration during the season was little changed, and the earlier planting achieved over double the WUE of the spring planting.

Currently, farmers in the Mediterranean region tend to sow crops later than the theoretical optimum time for several reasons. Initial rains are unreliable (Dennett et al., 1983) and early sown crops can germinate and then suffer severe drought or death in the subsequent weeks. Moreover, many farmers prefer to allow early rains to germinate weed seeds which can then be killed by pre-sowing tillage operations. This is particularly true in areas of high weed infestation and in food legume crops which are still largely dependent on hand weeding for lack of suitable herbicides.

Similarly, plant populations and spacings are under the control of the farmer and theoretically could be managed to achieve maximum ground cover during the winter months and yet still allow sufficient water to be available during grain-filling (Bolton, 1981)..In practice, though, this may be difficult because grain yield at the optimum population is often closely related to the water supply available for the growing season. For example, Anderson (1984) showed that the optimum population of triticale varied between about 80 and 190 plants $\mathrm{m}^{-2}$ (corresponding to seeding rates of 30 to $150 \mathrm{~kg} \mathrm{ha}^{-1}$ ) for grain yields ranging from 2.1 to $6.9 \mathrm{t} \mathrm{ha}^{-1}$; grain yield was linearly related to the seasonal water supply, with approximately $17 \mathrm{~kg}$ of grain $\mathrm{ha}^{-1} \mathrm{~mm}^{-1}$ water supply. In barley, ground cover and the number of tillers produced is frequently affected 
by sheep grazing (Anderson, 1985a) and this is sometimes used as a deliberate means of controlling plant population; low WUE may result from the reduced leaf area and ground cover.

A more immediate, practical means of increasing water use efficiency is by the application of fertilizers. As stated earlier in this review, phosphate is severely deficient in many soils of the Mediterranean region and so is nitrogen. Large responses to these fertilizers have been shown by barley and durum wheat (Cooper et al., 1981; Harmsen et al., 1983; Anderson, 1985b). Associated with the increased yields was an increase in the WUE (Table 7), mainly because the fertilizer increased the early growth of cereals by allowing more rapid growth of the leaves (Fig. 6) and these differences persisted until harvest (Gregory et al., 1984; Cooper et al., 1987). The increased leaf area shaded the damp soil surface, intercepting more of the incident radiation so that water which would otherwise have evaporated was transpired instead. Over the four seasons shown in Table 7, WUE was on average increased by $75 \%$ by the addition of fertilizers (see also Table 10) and there is no evidence to suggest that the use of water early in the season results in reduced yields at harvest. In some years when late rains are poor, fertilizer application can result in lower grain weight of cereal crops (Shepherd et al., 1987). Keatinge et al. (1985) found that such reductions in grain weight were associated with lower water potentials in the xylem of spikes of wheat and barley crops which had been given fertilizer. However, yields were still higher because reduced grain weight was more than compensated for by increased numbers of spikes and grains per spike. In very dry years, heavy nitrogen applications might give a large proportion of shrivelled grain, and so lead to reduced grain yields (Fischer and Kohn, 1966). However, Fischer (1981) concluded that the early exhaustion of a limited water supply can only partly explain such results and suggested that high concentrations of nitrogen in the plant may predispose it to injury through water stress.

Finally, plant breeding strategies can be focussed on developing cultivars specifically for improved water use efficiency. Fischer (1981), in reviewing such possibilities, concluded that cultivars which grow rapidly during the cool

Table 7. Effects of fertilizer ( $60 \mathrm{~kg} \mathrm{ha} \mathrm{H}^{-1} \mathrm{P}_{2} \mathrm{O}_{5}$ and $\mathrm{N}$ ) on yield and water use of barley (cv. Beecher) grown at Jindiress $\left(36^{\circ} 23^{\prime} N, 36^{\circ} 41^{\prime} E\right.$ ) in northern Syria

\begin{tabular}{|c|c|c|c|c|c|c|c|c|}
\hline Year & \multicolumn{2}{|c|}{$1979 / 80$} & \multicolumn{2}{|c|}{$1980 / 81$} & \multicolumn{2}{|c|}{$1981 / 82$} & \multicolumn{2}{|c|}{$1982 / 83$} \\
\hline Rainfall (mm) & \multicolumn{2}{|c|}{367} & \multicolumn{2}{|c|}{454} & \multicolumn{2}{|c|}{319} & \multicolumn{2}{|c|}{360} \\
\hline Fertilizer & - & + & - & + & - & + & - & + \\
\hline 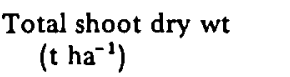 & 3.8 & 6.6 & 5.4 & 12.5 & 4.4 & 8.7 & 6.6 & 11.0 \\
\hline Grain dry wt $\left(\mathrm{tha}^{-1}\right)$ & 1.7 & 2.9 & 2.3 & 5.0 & 1.4 & 2.9 & 3.1 & 4.7 \\
\hline $\begin{array}{l}\text { Total water use (evapo- } \\
\text { transpiration } \mathrm{mm} \text { ) }\end{array}$ & 272 & 322 & 323 & 376 & 323 & 316 & 333 & 356 \\
\hline WUE $\left(\mathrm{kg} \mathrm{ha}^{-1} \mathrm{~mm}^{-1}\right)$ & 14.0 & 20.5 & 16.7 & 33.2 & 13.6 & 27.5 & 19.8 & 30.1 \\
\hline
\end{tabular}




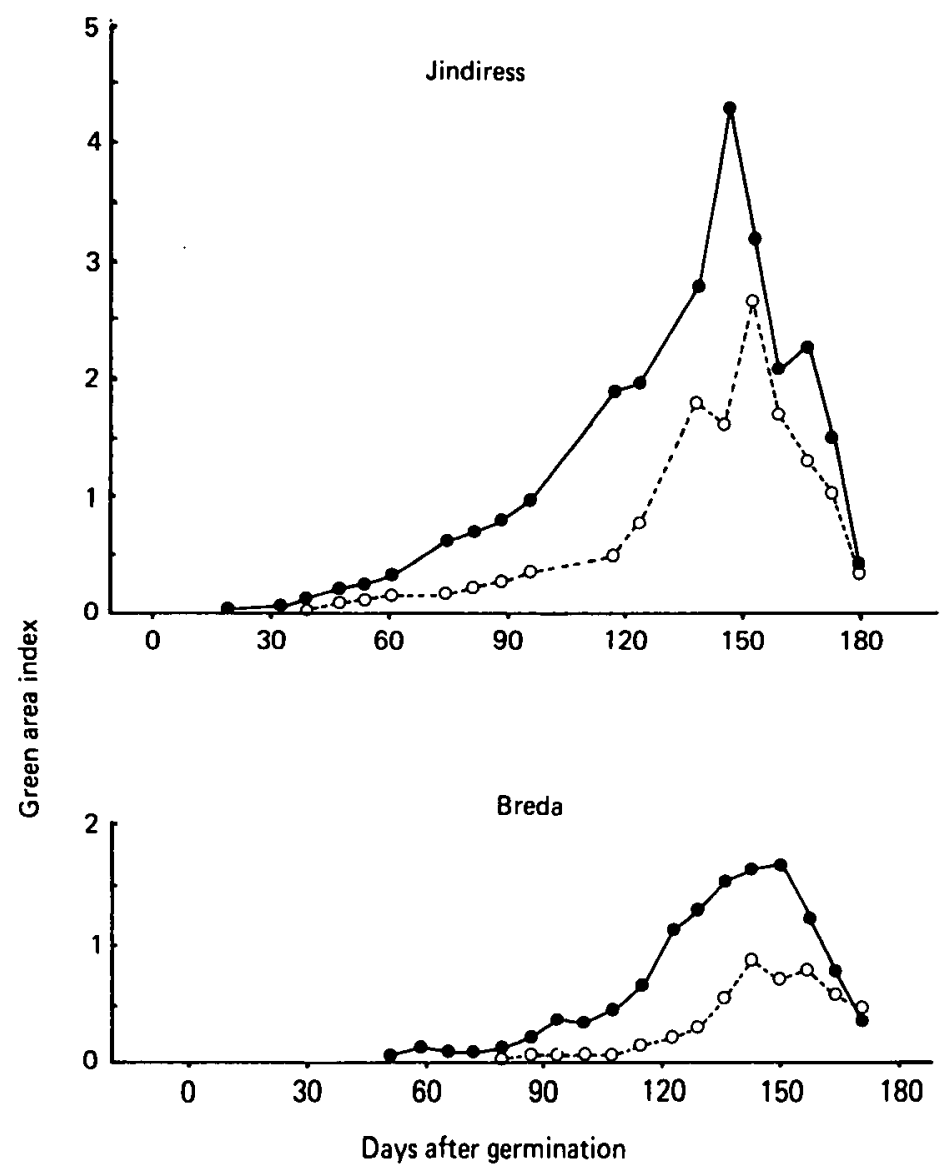

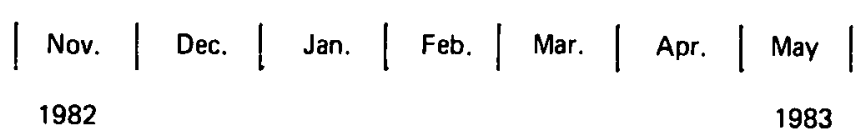

Fig. 6. Development of green area index of barley (cv. Beecher) at two locations in NW Syria in the presence $\left(\bullet-\bullet, 60 \mathrm{~kg} \mathrm{ha}^{-1} \mathrm{P}_{2} \mathrm{O}_{5}, 40 \mathrm{~kg} \mathrm{ha}^{-1} \mathrm{~N}\right)$ and absence $\left(\mathrm{o}_{--0}\right)$ of fertilizer, 1982/83.

winter months offer the most promising strategy for improved WUE through both higher transpiration efficiencies and more rapid shading of the soil surface. He also suggested that varieties which produce a high density of roots in the surface soil layers, rapidly re-activated following rain showers, would help reduce soil evaporation losses. Crop morphology can also be manipulated to optimize the interception of radiant energy during early growth and thus reduce soil evaporation and increase transpiration. Comparison of two chickpea cultivars with constrasting growth habits showed that the spreading type achieved a substantially greater WUE than the erect type (6.9 compared with $3.8 \mathrm{~kg} \mathrm{ha}^{-1} \mathrm{~mm}^{-1}$ for grain yield across three locations; ICARDA, 1982, pp. 23-28). Nonetheless, whilst such manipulation of plant characteristics remains a goal for plant breeders, it appears that the most immediate and dramatic increases in WUE will be achieved through improved crop management. 


\section{Increasing total water use}

Many management practices are used to increase the water available to a crop (Table 6) and provided that this water is transpired and does not simply increase soil evaporation, increased growth will result. Supplementary irrigation and rain-harvesting have been used around the Mediterranean for many centuries to increase the water supply available to crops and many ancient underground systems for water delivery still exist. The efficiency with which irrigation water is converted to dry matter depends on many factors beyond the scope of this review, including the design of the system, the method of application, and the timing and amount of application. In general, though, WUE is rarely as high as in rainfed conditions because irrigation schemes are often sited in more arid areas which experience larger saturation deficits. For example, Ismail (1974) showed that near Baghdad the WUE of wheat given no fertilizer (grain yield only) ranged from 5.3 to 5.4 to $7.2 \mathrm{~kg} \mathrm{ha}^{-1} \mathrm{~mm}^{-1}$ for irrigations of 492,410 and $328 \mathrm{~mm}$, respectively; application of fertilizer $\left(80 \mathrm{~kg} \mathrm{~N} \mathrm{ha}^{-1}\right.$ and $40 \mathrm{~kg} \mathrm{P} \mathrm{ha}^{-1}$ ) raised WUE to $6.7,8.9$ and $9.7 \mathrm{~kg} \mathrm{ha}^{-1} \mathrm{~mm}^{-1}$, respectively.

As has been indicated, weeds pose severe problems in many farmers' fields in the Mediterranean region, particularly in the wetter and warmer areas. They can dramatically decrease the WUE of crop production, particularly in food legume crops which compete less vigorously with weeds. During the cool winter months, when transpiration by crops and weeds is small, weedy crops use only marginally more water than clean crops. However, during late spring and early summer, weeds compete vigorously for available moisture and suppress crop growth and yield considerably. This is illustrated by data (Table 8 ) from a study on weed control in lentils in NW Syria where, across fertilizer and tillage treatments, weed control increased the WUE of dry matter production in lentils

Table 8. Effect of hand weeding and fertilizer $\left(60 \mathrm{~kg} \mathrm{ha}^{-1} \mathrm{P}_{2} \mathrm{O}_{5}\right.$ and $20 \mathrm{~kg} \mathrm{ha}^{-1}$ $N)$ on water use, yield and water use efficiency of lentil production under contrasting tillage techniques in NW Syria (1983)

\begin{tabular}{|c|c|c|c|c|c|c|c|c|c|}
\hline \multirow{2}{*}{$\begin{array}{l}\text { Ferti- } \\
\text { lizer }\end{array}$} & \multirow{2}{*}{$\begin{array}{l}\text { Weed } \\
\text { control }\end{array}$} & \multicolumn{5}{|c|}{$\begin{array}{l}\text { Accumulated water use }(\mathrm{mm} \text { ) } \\
\text { (Lentils sown on } 25 / 10 / 82 \text { ) }\end{array}$} & \multicolumn{2}{|c|}{$\begin{array}{c}\text { Dry matter } \\
\left(\mathrm{kg} \mathrm{ha}^{-1}\right) \dagger\end{array}$} & \multirow{2}{*}{$\begin{array}{l}\text { WUE of lentil } \\
\text { dry matter } \\
\text { production } \\
\left(\mathrm{kg} \mathrm{ha}^{-1} \mathrm{~mm}^{-1}\right)\end{array}$} \\
\hline & & $3 / 1$ & $10 / 2$ & $17 / 3$ & $5 / 4$ & $10 / 5$ & Lentil & Weeds & \\
\hline \multicolumn{10}{|c|}{ Conventional tillage } \\
\hline+ & - & 32 & 67 & 124 & 183 & 270 & 1128 & 1084 & 4.2 \\
\hline+ & + & 33 & 59 & 106 & 159 & 237 & 2038 & 37 & 8.6 \\
\hline- & - & 31 & 59 & 107 & 158 & 255 & 667 & 685 & 2.6 \\
\hline- & + & 33 & 59 & 104 & 152 & 218 & 751 & 72 & 3.4 \\
\hline \multicolumn{10}{|c|}{ Zero tillage } \\
\hline+ & - & 40 & 70 & 126 & 190 & 275 & 970 & 1723 & 3.5 \\
\hline+ & + & 33 & 60 & 104 & 158 & 260 & 2161 & 143 & 8.3 \\
\hline- & - & 36 & 67 & 118 & 165 & 272 & 336 & 1582 & 1.2 \\
\hline - & + & 33 & 59 & 100 & 140 & 224 & 767 & 87 & 3.4 \\
\hline
\end{tabular}

$\dagger$ Full details of LSDs associated with dry matter production comparisons are reported in ICARDA (1984) pp. 31-40. 
from 2.9 to $5.9 \mathrm{~kg} \mathrm{ha}^{-1} \mathrm{~mm}^{-1}$. Similar results have been demonstrated for weed control in cereal crops (wheat and barley) in both west Asia and north Africa (Hepworth et al., 1975; ICARDA, 1983, p. 10; ICARDA, 1985, p. 10). Where suitable herbicides are available to farmers, they are frequently used, although as mentioned earlier many farmers still prefer to hand-weed cereal crops for fodder supply.

Deep tillage is used on some soil types particularly in north African countries, to reduce run-off and improve infiltration, although its effectiveness in conserving soil water for a succeeding crop may be limited if appreciable drying occurs during the hot summer months (see Tamini and Young, 1980, for an example in northern Iraq). Fallowing is also used to increase the amount of water available for the next season although the amount available is highly dependent upon soil depth, type and whether weeds are controlled. In the Great Konya Basin of Turkey, Janssen (1972) calculated that water stored during the fallow year contributed between 45 and $65 \%$ of the water transpired by succeeding wheat crops. However, many soils in the Mediterranean region contain appreciable quantities of swelling clay and, as Fig. 7 shows, although water may be stored in the profile during the winter period, it is mostly lost by evaporation during the hot, dry summer and only a small proportion (15 to $25 \%$ of the season's rainfall) is available to a succeeding winter crop. As an alternative, summer crops may be grown on this stored water. In contrast, sandy soils

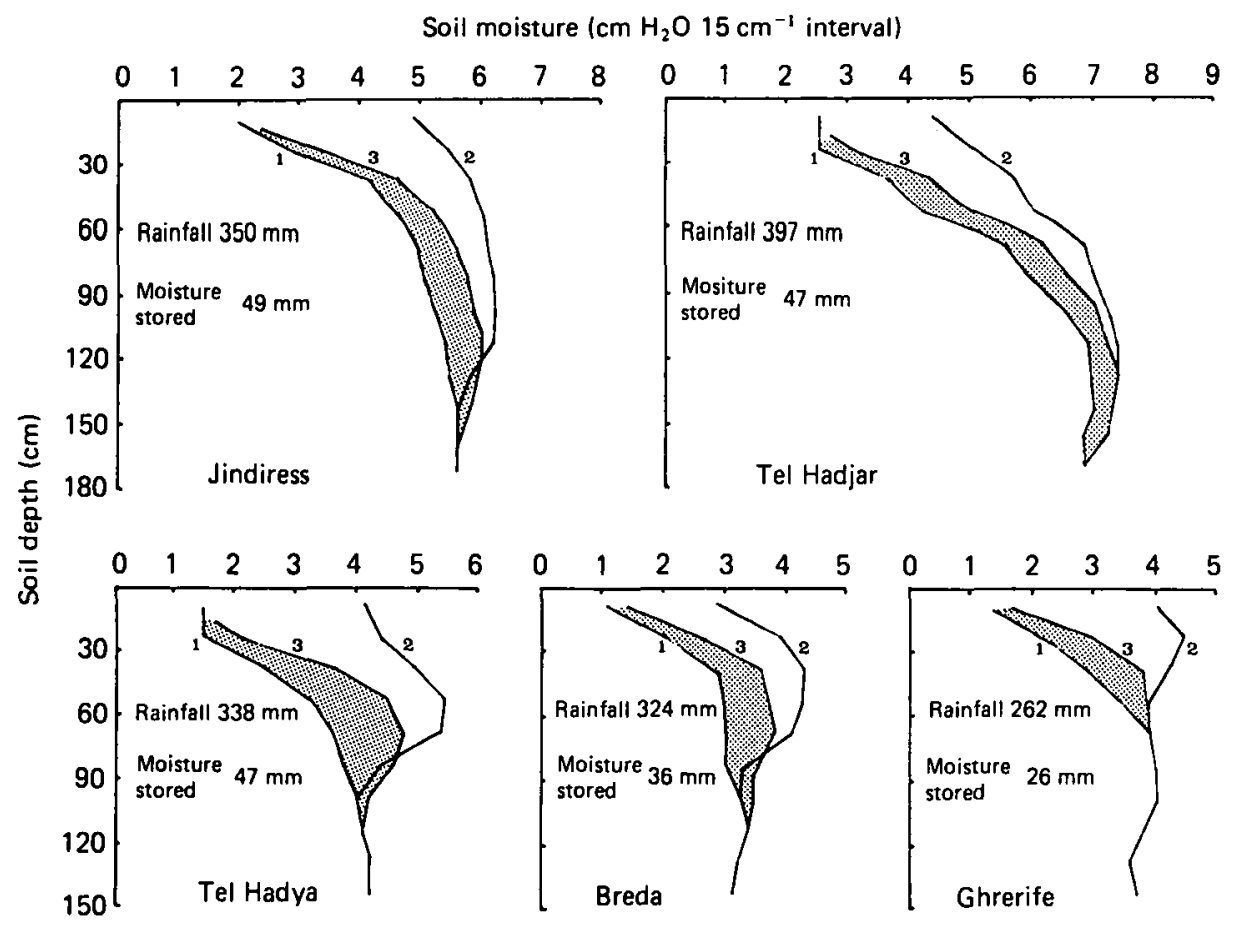

Fig. 7. Distribution of soil moisture under fallow land at five locations in NW Syria on three selected dates: (1) at start of rainy season, (2) maximum profile recharge and (3) at the end of the summer dry season. Shaded areas represent moisture stored during the fallow period. 1981/82. 
may form a dry mulch and in Algeria, Perrier (1973) showed that the formation of a mulch was a determining factor in the water balance of fallows and thence on wheat yields in a wheat/fallow rotation. In the Pacific Northwest, USA, cultivation to produce a mulch together with residue management and stubble mulching have been successfully employed to improve the water storage of fallow soil (Lindstrom et al., 1974; Bolton, 1981; Caprio et al., 1985).

Application of fertilizer also tends to increase slightly the total water use of crops, either by increasing the depth of water extraction (Brown, 1971) or increasing the amount extracted from specific soil layers or both. Fertilizer application increased the amount of water used in three of the four growing seasons considered in Table 7 although the additional water used was at most $15 \%$ of the total (see also Table 10 for results at a drier site where total water use was increased by up to $10 \%$ ).

It is frequently suggested that improvements to root systems may increase water use by crops. Even in dry areas, water often remains in the deeper layers of the soil at the end of crop growth and crops with deeper root systems should be able to extract this water and thereby enhance growth. However, in much of the Mediterranean region, there is little drainage from the profile and the depth of wetting by one season's rainfall normally determines both the seasonal depth of drying and, by implication, the depth of rooting (see Gregory et al., 1984). In certain instances, available water from the previous season is stored below the depth of wetting, and becomes available for crop uptake providing the wetting front joins up with this stored water. Such instances occur where fallowing is practised, and also in continuous cropping following years of high rainfall when not all the stored moisture is used (Stapper and Goebel, 1985). In general, however, water below the depth of wetting must be regarded as fossilized and is only extractable once, or only once between years of high rainfall. Deeper rooting is, then, unlikely to be beneficial. However, differences between varieties in the distribution of roots and timing of water extraction may contribute to differences in WUE. Brown et al. (1987) have shown that, in Syria, a local landrace barley had a longer root system below $15 \mathrm{~cm}$ than a more widely adapted variety (Fig. 8) and that under dry conditions (less than $350 \mathrm{~mm}$ rainfall) this was associated with earlier and slightly greater water use from the deeper soil layers (see also Cooper et al., 1987). A larger root system towards the base of the wetted layer may be beneficial to water uptake provided that water is not used so rapidly as to leave none during grain-filling.

In conclusion, transpiration efficiency $(\mathrm{DM} / \mathrm{T})$, the balance between soil evaporation and crop transpiration (i.e. the ratio $E_{S} / T$ in Equation 4 ) and the total water available to and used by the crop can all be beneficially modified by innovative agricultural practices. However, we agree with Ritchie (1983) that the largest increases in the WUE of rainfed crop production will result from changing the ratio of the two components of evapotranspiration, namely soil evaporation and crop transpiration. 


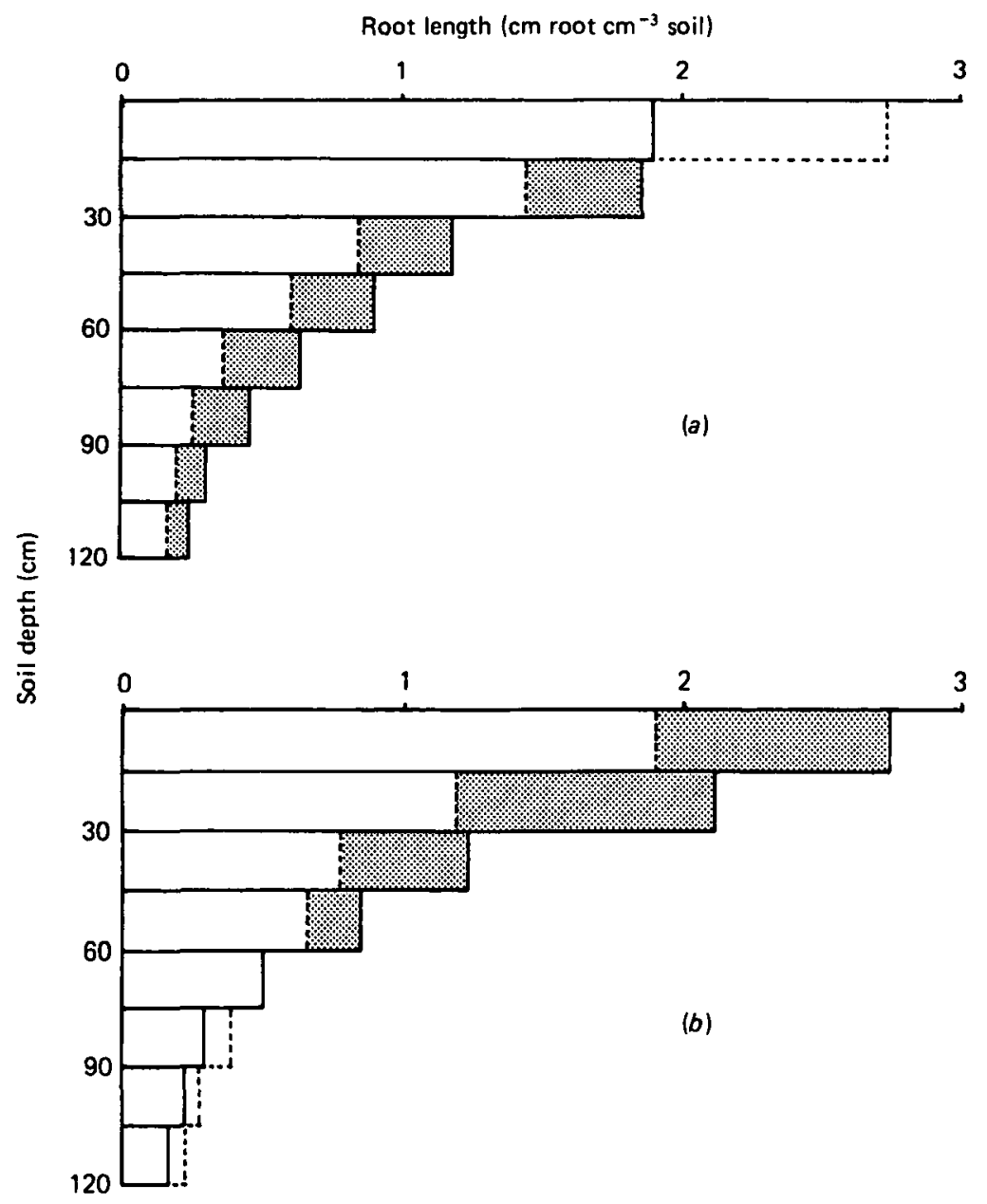

Fig. 8. Root length distribution of barley at Jindiress, NW Syria: (a) comparison of two varieties, Arabic Abiad (local landrace variety, solid bars) and Beecher (dotted bars); (b) effect of fertilizer, $60 \mathrm{~kg} \mathrm{ha}^{-1}$ $\mathrm{P}_{2} \mathrm{O}_{5}, 40 \mathrm{~kg} \mathrm{ha}^{-1} \mathrm{~N}$ (solid bars) and no fertilizer (dotted bars). 1982/83.

THE BARLEY/LIVESTOCK FARMING SYSTEMS OF NW SYRIA: A CASE STUDY

\section{Introduction}

Simmonds (1986), in the introductory paper to this series, identified three types of Farming Systems Research currently practised by international and national agricultural research centres. In this section, we conclude our review by summarizing seven years on-going research conducted by the Farming Systems Programme of ICARDA (The International Centre for Agricultural Research in Dry Areas) as a case study of OFR/FSP, or 'on farm research with farming systems perspective' (Simmonds, 1986).

Simmonds recognized ten initial steps in OFR/FSP and we shall present this case study within his framework as an example of the valuable and applied nature of OFR/FSP style research. It is written from the perspective of the 
international agricultural research centres, but we believe that such an approach is also suitable and relevant to the goals of national agricultural research centres with whom the international centres work.

\section{The Farming Systems Programme at ICARDA}

ICARDA has four principal research programmes: the Food Legume Improvement Programme (FLIP), the Cereal Improvement Programme (CP), the Pasture, Forage and Livestock Improvement Programme (PFLIP) and the Farming Systems Programme (FSP).

FSP consists of a multi-disciplinary group of scientists and support staff with specialization in agronomy, soil physics, soil chemistry, agroclimatology, water management, livestock science, sociology, anthropology, economics and training. The programme works in close collaboration with ICARDA's other programmes which contain specialists in the fields of plant breeding, pasture management, livestock management, entomology, crop physiology, microbiology and computer sciences. Many of the projects undertaken at ICARDA are cooperative efforts between two or more of the programmes.

Given ICARDA's mandate for the rainfed farming systems of west Asia and north Africa, FSP, as one of its overall objectives, seeks to identify innovative farming practices which will lead to more efficient use of the region's most scarce resource, namely water.

\section{The identification of 'target' farming systems}

Barley is the second most important crop of the region (Table 4) and among the international research centres of the CGIAR system, ICARDA has been given global responsibility for barley research. Within the region, many of the national programmes have rightly focussed their research and extension on the wetter areas with better potential where wheat, food legumes and summer crops are predominantly grown, and little information has been available on the problems and potential of the dryland barley growing areas.

Given ICARDA's responsibility for barley research, the importance of barley within the region as a livestock feed, and the lack of research and information on the barley producing systems of the region, the FSP identified these systems as a high priority area of research, and formulated a Barley/Livestock research project. Initially, much of our research within the project has focussed on the barley/livestock systems of NW Syria, close to ICARDA's headquarters at Aleppo, but as our experience increases our research is expanding to other similar areas within the region.

\section{Agricultural and economic structure}

Several surveys were conducted within the project area and have been reported in detail elsewhere (Somel et al., 1984; Tully, 1984; Jaubert and Oglah, 1985). In addition to these area surveys, detailed monitoring of farm activities and crop and livestock performance was conducted in specific cases (Jaubert 
and Thomson, 1985). The essential characteristics of these farming systems are summarized below.

Farms tend to be small and family operated (Plate 2f). In a survey of 678 farms in 20 villages near Breda in NW Syria mean farm size was 14.9 ha with a distribution similar to that shown for the whole of Syria in Table 5 (Jaubert and Oglah, 1985), although somewhat larger farms are found in the northeast of the project area (Somel et al., 1984). Eighty six per cent of farm households own some or all of their land, $20 \%$ rent land from other farmers, and $16 \%$ rent land from the state. Mean family size is 10.5 and the farm provides, on average, $74 \%$ of family income with off-farm employment increasingly important on the smaller farms and in the drier parts of the project area (Somel et al., 1984).

Barley is the most important crop in the northwest where mean annual rainfall is $350 \mathrm{~mm}$ or less. The second most important crop is wheat which is grown even in fairly dry areas, in amounts which largely meet domestic needs. Legumes, primarily lentil (Lens culinaris), vetch (Vicia sativus) and lathyrus (Lathyrus sativa) are found, as are summer crops, primarily melons. However, the area of these crops decreases where rainfall is below $350 \mathrm{~mm}$ and is less than $4 \%$ of the rainfed crops area below $300 \mathrm{~mm}$ (Tully, 1984; Jaubert and Oglah 1985). Tree crops such as olives, grapes and pomegranate are also grown to a limited extent. In many parts of the project area, 20-30\% of the land consists of steep and rocky hillsides which cannot be cultivated and these are used as communal village grazing areas for livestock.

In wetter areas and on better soils, barley may be grown in rotation with legumes, summer crops or both. However, the most common rotation is barleyfallow, found on $60 \%$ of the barley plots surveyed. Continuous barley was grown on $20 \%$, and two years of barley followed by one year of fallow on $11 \%$ (Somel et al., 1984) (Plate 3a).

Because of the variability in rainfall and barley yields, the use of inputs for barley production is considered risky. Yields are generally poor, farmer expectations of average grain yields varying from about 500 to $1000 \mathrm{~kg} \mathrm{ha}^{-1}$ depending on the location and year. According to the results of a survey of barley growers in northern Syria, less than $15 \%$ use fertilizer, and government supply and credit policies have not encouraged fertilizer use in these dry areas (Somel et al., 1984).

Lack of inputs of either chemical or animal manure has led to a decline in soil fertility, and deficiencies of nitrogen and phosphorus in farmers' fields are widespread and, in many instances, chronic (Harmsen, 1984a). During the last twenty years farmers estimate that their barley yields have halved. As a result of declining yields and increased demand for fodder, farmers are expanding the cultivation of barley onto more and more marginal soils, and the practice of fallowing is on the decline with continuous barley cropping becoming more common (Jaubert and Oglah, 1985).

Although farms are small, several major crop production operations are mechanized. While crops are almost always sown by hand broadcasting, seed 
bed preparation and seed covering are done by tractors on $96 \%$ of the farms surveyed, and $35 \%$ of the area is harvested by combine. When yields are low, barley is frequently harvested by hand to maximize straw yields, but threshing is almost always done mechanically (Plate $3 \mathrm{~b}$ ). Farmers seldom own the machinery, but contract services are readily available (Somel et al., 1984).

Most farmers own livestock, principally sheep, but flock size is variable. In a survey of 20 villages, over $80 \%$ of the 678 farmers owned livestock, with flock size varying from 3-600 head. These flocks fall into two broad categories: large transhumant flocks of over 100 head which move considerable distances inland to the rangeland at certain times of year, and smaller flocks averaging only 20-25 head which remain in the village throughout the year. The transhumant flocks represent only about $40 \%$ of the flocks but account for $78 \%$ of the sheep population (Jaubert and Oglah, 1985).

Barley grain and straw are used almost entirely to feed sheep, and account for over $60 \%$ of their metabolic requirements (Jaubert and Oglah, 1985). The cycle of sheep feeding for the project area is illustrated in Fig. 9. In spring, grazing on fallow and communal grazing areas provides most of the sheep's feed requirements in an average or good year, while in summer, crop stubbles and residues are an abundant feed source. Standing crops on poor fields are also commonly used as summer feed; this appears to be done when farmers consider that the value of the grazed crop is higher than that of the harvested crop net of costs (Nordblom, 1983; Mazid and Hallajian, 1983). For instance, farmers surveyed in 1981 grazed $28 \%$ of their barley, while in the poorer 1982 crop year they grazed $49 \%$ (Somel et al., 1984).

In autumn and winter, inexpensive feed sources are scarce, and animals are fed conserved feed. This consists primarily of barley grain and straw as well as wheat straw and purchased agro-industrial by-products such as cotton seed cake (Jaubert and Thomson, 1985).

In drought years, such as $1983 / 84$, the normal feeding cycle is severely disrupted as the feed supply from the communal grazing areas is drastically reduced and winter supplementary feeding is extended (Plate 3c). Grazing areas cannot support the flocks and farmers are forced to graze their barley during the early vegetative stage through to harvest. This practice greatly reduces the availability of stored feed for the next winter, but allows the farmers to fatten lambs for sale and reduce the number of ewes in their flocks. By June, the feed supply in the villages is exhausted and the sheep are moved to wetter areas where they are fed on rented wheat stubble and summer crop residues. In 1983/84 an estimated three million sheep had to be slaughtered because of shortages in feed supply, illustrating the fragile nature of the barley/livestock farming systems.

\section{The barley growing environment}

Rainfall is highly seasonal and occurs almost exclusively from October to May; no effective rain falls in the remainder of the year. At the start (OctoberNovember) and end (April-May) of the rainy season much of the rain occurs as 

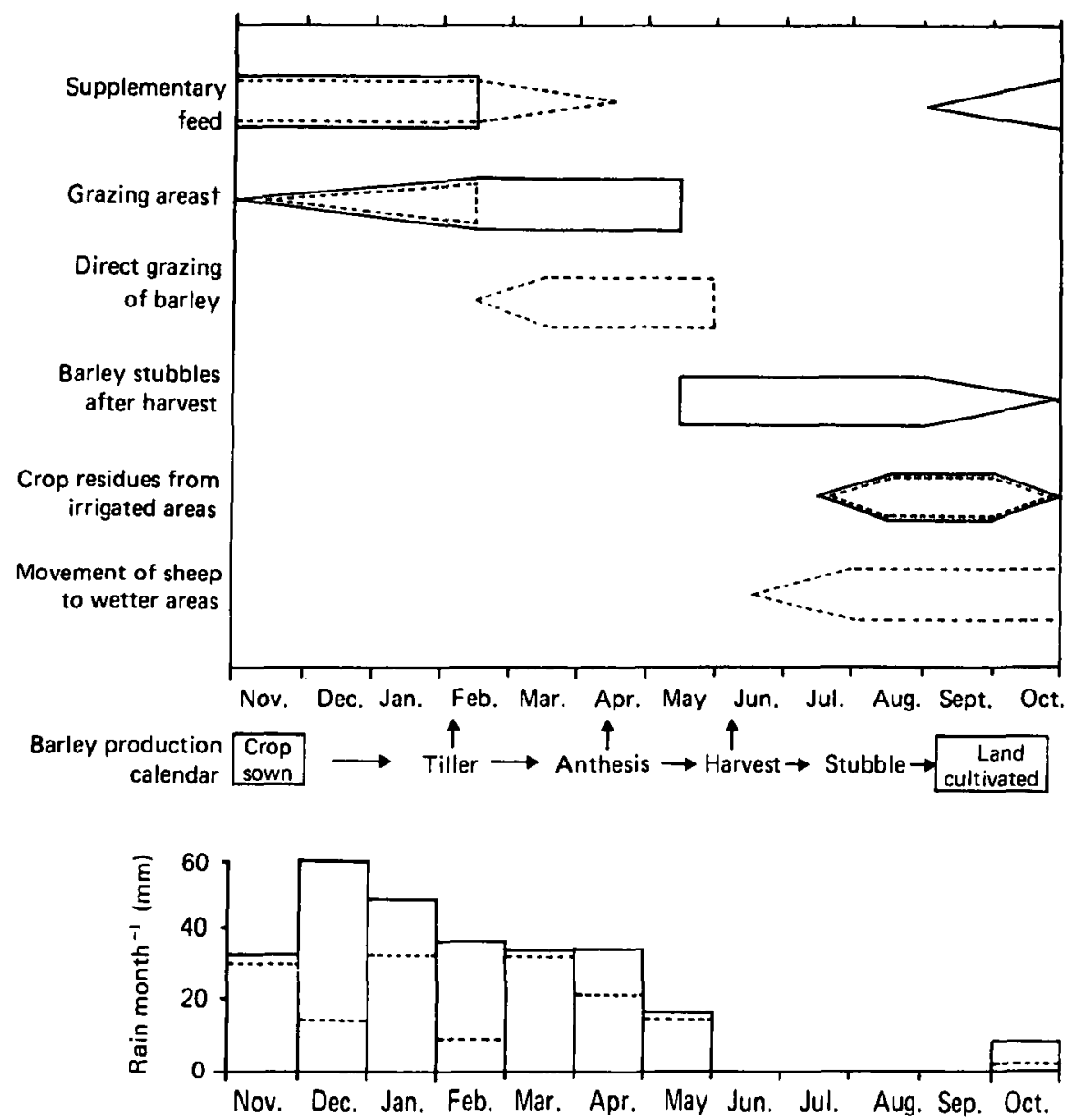

†Village based flocks utilize local marginal grazing areas. Transhumant flocks move to steppe land in spring for grazing.

Fig. 9. Livestock feeding cycle at Bueda/Breda in NW Syria. Solid lines represent normal feeding practice, and dotted lines those observed in the drought year of $1983 / 84$.

convective thunderstorms, which frequently affect only isolated areas. For the remainder of the season rain events, associated with major fronts, are more general in distribution and may last for several days. Rainfall intensities may be quite high during thunderstorms, but otherwise are low, and much of the rain occurs as falls of less than $5 \mathrm{~mm}$ a day (Sabet and Harris, 1986).

Not only is annual rainfall low, it is highly variable both between and within seasons (Fig. 10a and 10b). The average distribution in the west of the area shows a peak in late January-early February, but in the east rainfall later in the season is more reliable and the distribution somewhat more uniform.

Temperatures restrict plant growth at two stages of the season. In winter mean daily temperatures limit growth and occasional frost damage occurs, whilst during the spring there is a rapid increase in temperature in late April 

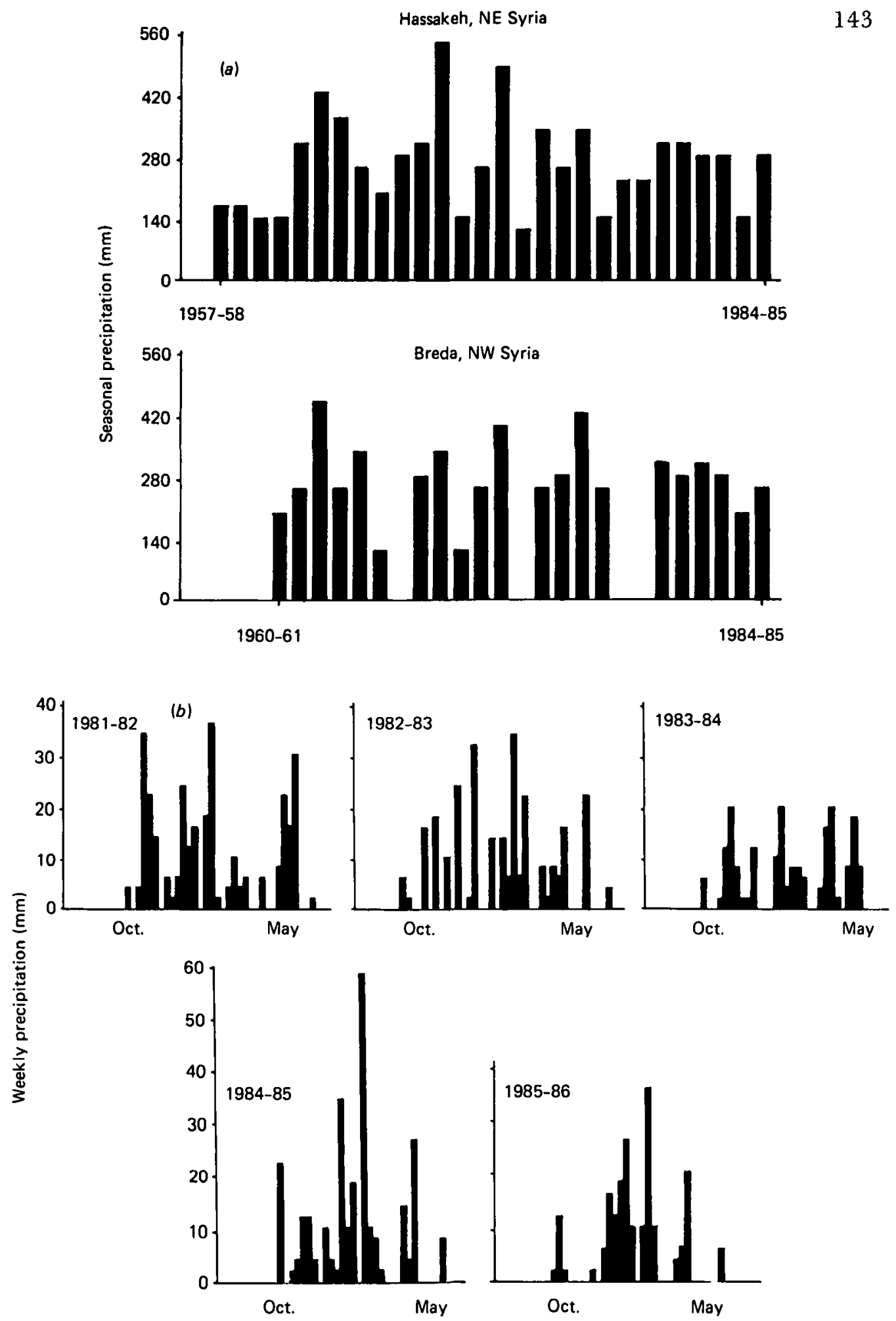

Fig. 10. Inter- and intra-seasonal variability in rainfall: (a) seasonal totals at Hassakeh (NE Syria) and Breda (NW Syria); data were not available for four years at Breda; (b) weekly totals for five seasons at Breda (NW Syria). 
and May (Fig. 11). These high temperatures coincide with the end of the rains and are accompanied by a sharp increase in evaporation rates. The final stage of crop development (grain filling) invariably takes place in conditions of water and high temperature stress.

The soils of the area are classified as calcic or gypsic Xerosols (FAO/Unesco system). Harmsen (1984a) surveyed soils in some of the barley-growing areas. All are calcareous, containing from 25 to $50 \%(\mathrm{w} / \mathrm{w})$ of calcium carbonate. Gypsum is present in many profiles and gypsic horizons occur at between 30 and $100 \mathrm{~cm}$ depending on location. Their $\mathrm{pH}$ is of the order of 7.5 to $8.5(1: 1$ $w / v)$, and some profiles show electrical conductivity values which indicate the presence of excess sodium. Organic matter contents are universally less than $2 \%$ and frequently less than $1 \%$; $\mathrm{C}: \mathrm{N}$ ratios generally are low, no doubt contributing to the observed low microbial populations (Stephens, personal communication). In general, plant-available nitrogen contents in the top $20 \mathrm{~cm}$

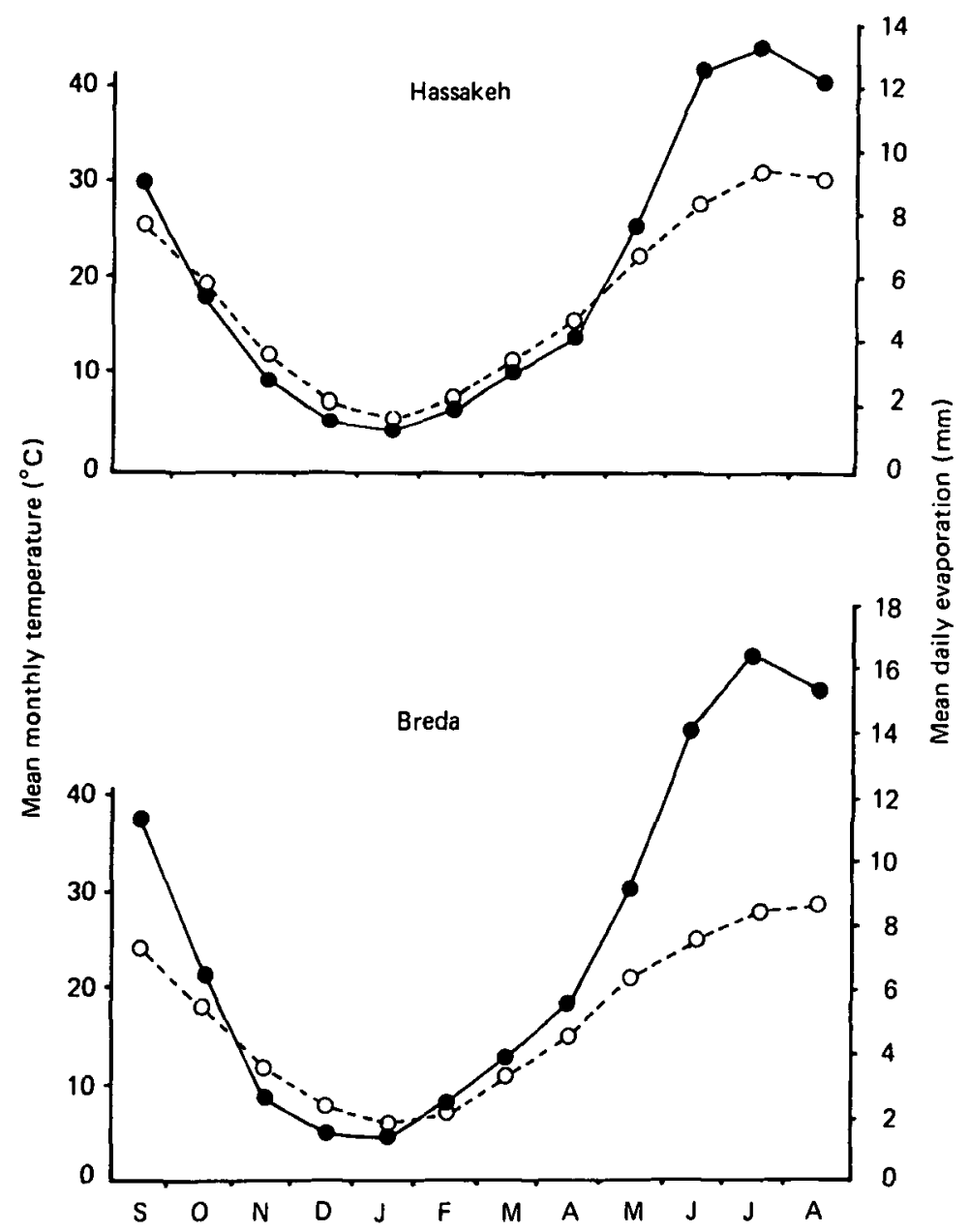

Fig. 11. Mean monthly temperature $\left(0^{---o}\right)$ and mean daily pan evaporation ( $\left.-\bullet\right)$ at Hassakeh (NE Syria) and Breda (NW Syria). 
appear satisfactory for plant growth and $\mathrm{NO}_{3}-\mathrm{N}$ tends to increase with depth. In contrast, available phosphorus (Olsen) is generally less than $6 \mathrm{ppm}$ at the surface and decreases with depth, largely due to the domination of soil chemistry by the high calcium carbonate content.

The generality of these findings has been confirmed through routine soil analysis of on-farm trial sites over several seasons and across many locations.

Soil texture varies from silty clay and clay (predominantly montmorillonite) to loam and silt loam as rainfall decreases (Harmsen, 1984a). High silt content in some soils leads to surface dispersion under high intensity rainfall, resulting in surface-sealing and impedence of water infiltration and plant emergence.

The water-holding capacity of the soils is about $270 \mathrm{~mm} \mathrm{~m}^{-1}$ of soil depth, and approximately $20 \%$ of this water can be used by plants. During the long, hot, dry summers characteristic of the area the upper part of the profile tends to air-dry, so substantial rainfall is required at the start of the season before sufficient water to promote germination is stored.

Studies of soil water dynamics over the last seven seasons have shown that water balance is positive in the first half of the season and that maximum profile recharge normally occurs at about the end of February. From that time increased plant growth, as temperatures rise, causes net discharge and all plant extractable water is used by, or before, crop maturity. The depth of wetting varies with the total seasonal rainfall, and its distribution through the season. Maximum seasonal depths in the past seven years at one site have varied from 30 to $105 \mathrm{~cm}$ with rainfall of 204 and over $270 \mathrm{~mm}$, respectively.

The efficiency of rainfall storage depends on the amount of rain per rainday. Because a high proportion of rain-days yield less than $5 \mathrm{~mm}$, much is quickly lost through soil evaporation even during the winter when evaporation rates of around $1 \mathrm{~mm}$ per day prevail. As rainfall per day increases a greater proportion is stored. Principles associated with the manipulation of these balances were discussed in Section 2 of this review.

\section{Identification of research goals}

On the basis of the information gathered and that available from similar environments in other parts of the world, two principal research goals were identified.

First, given the obvious importance of livestock in these farming systems and the low, variable and declining yields of barley, their principal source of feed, economically viable strategies to improve the growth, yield and water use efficiency of barley in the dry areas are of the utmost importance. Secondly, given the poor water storage efficiency of fallow in these hot and arid environments and the general shortage of forage for livestock, it seemed important to find out to what extent the fallow can be replaced either by continuous barley cultivation or by the introduction of annually sown forage legume species, and to assess the comparative water use efficiencies (over a two year period) of fallow/barley, barley/barley and forage legume/barley crop rotations. 
Both these research objectives are currently being pursued, with successful results. In this review, we focus on the progress made in improving the water use efficiency of barley production. Research on the potential for introducing forage legumes has been reported in detail elsewhere (ICARDA 1982, 1983, $1984,1985,1986)$.

\section{On-station and on-farm research}

ICARDA's principal research site at Tel Hadya (mean rainfall $350 \mathrm{~mm}$ ) is not representative of the target farming systems, so two semi-permanent sites of 10 ha each were established in the project area southeast of Aleppo at Breda $\left(35^{\circ} 55^{\prime} \mathrm{N}, 37^{\circ} 10^{\prime} \mathrm{E}\right)$ and Khanasser $\left(35^{\circ} 45^{\prime} \mathrm{N}, 37^{\circ} 32^{\prime} \mathrm{E}\right)$ with long term mean rainfalls of 275 and $215 \mathrm{~mm}$, respectively. Diagnostic experiments on barley were conducted to determine the possible importance of a range of agronomic practices, including time and method of sowing, seeding rate, genotype, weed control and nitrogen and phosphate fertilizer. The results of these studies have been reported in considerable detail elsewhere (Cooper et al., 1981; ICARDA, 1982, pp. 4-10; ICARDA, 1983, pp. 8-12). Fertilizer use, and in particular the use of phosphate, gave the most constant, substantial and economic increases in barley yield in a range of seasonal conditions. For instance, in $1981 / 82$ the increase in net benefit from the application of $60 \mathrm{~kg} \mathrm{ha}^{-1}$ $\mathrm{P}_{2} \mathrm{O}_{5}$ to barley was 996 and 567 Syrian Lira ha ${ }^{-1}$ at Breda and Khanasser, respectively (10 Syrian Lira $=1$ US $\$$ approx.) (ICARDA, 1983, pp. 10-11). These economic returns were calculated from grain and straw yields in the year of fertilizer application, but responses to residual phosphate in subsequent years are common and would further enhance the economic rates of return (ICARDA, 1983, p. 11; ICARDA, 1986). A typical set of responses obtained in a $2^{5}$ factorial trial to a range of agronomic practices is shown in Table 9.

Because the early fertilizer work indicated considerable potential for increasing yields, and because nutrient deficiencies appeared widespread, an intensive research programme was developed to investigate fertilizer response and to discover whether the early results would be sustained over a longer period. In particular, it was important to know the effect of fertilizer use on the water balance of a system where water is a major factor limiting growth.

A series of trials was conducted over a four to five year period, and some are continuing. The trials were carried out within the fallow-barley rotation common in the area. The trials were drilled with and without fertilizer ( $P$ and $N)$ and the water dynamics measured using neutron probes (Plate $3 \mathrm{~d}$ ). Crop water use was calculated between germination and maturity using the standard water balance equation and the efficiency of water use estimated in $\mathrm{kg} \mathrm{ha}^{-1} \mathrm{~mm}^{-1}$ of water use.

The results for the cropping seasons $1980 / 81$ to $1984 / 85$ at Breda are shown in Table 10. These clearly show that the increase in both total dry matter and grain yield with the use of fertilizer was consistent from year to year, even in the very dry year of $1983 / 84$ when farmers' crops largely failed in the project 
Table 9. Main effects and first order interactions of nitrogen, phosphate, weed control, genotype and seed rate on barley grain yield $\left(t h a^{-1}\right)$ at three locations in NW Syria, 1982/83

$\begin{array}{llll}\begin{array}{l}\text { Location } \\ \text { Seasonal rainfall }(\mathrm{mm})\end{array} & \begin{array}{c}\text { Breda } \\ 284\end{array} & \begin{array}{c}\text { Ghrerife } \\ 232\end{array} & \begin{array}{c}\text { Khanasser } \\ 295\end{array} \\ \text { Main effects } & & & \\ +\mathrm{N}\left(20 \mathrm{~kg} \mathrm{ha}^{-1} \mathrm{~N}\right) & 0.77 & 1.10^{* *} & 0.95 \\ -\mathrm{N} & 0.74 & 0.95 & 0.95 \\ +\mathrm{P}\left(45 \mathrm{~kg} \mathrm{ha}^{-1} \mathrm{P}_{2} \mathrm{O}_{\mathrm{s}}\right) & 0.99^{* *} & 1.22^{* *} & 1.02^{* *} \\ -\mathrm{P} & 0.52 & 0.85 & 0.89 \\ +\mathrm{W} \text { (Bromoxynil }+\mathrm{MCPA}) & 0.83^{* *} & 1.09 * & 0.98 \\ -W & 0.68 & 0.96 & 0.93 \\ \text { Improved cv. (Beecher) } & 0.68^{* *} & 1.08^{*} & 0.97 \\ \text { Local var. (Arabic Aswad) } & 0.83 & 0.97 & 0.94 \\ \text { High seed rate, } \mathrm{S}_{\mathrm{H}}\left(100 \mathrm{~kg} \mathrm{ha}^{-1}\right) & 0.80^{* *} & 1.08^{*} & 1.03^{* *} \\ \text { Low seed rate, } \mathrm{S}_{\mathrm{L}}(60 \mathrm{~kg} \mathrm{ha} & 0.87 \\ \text { SE ( }) & 0.70 & 0.97 & 0.02\end{array}$

Interactions

$\mathrm{N} \times \mathrm{P}$

$-\frac{2}{2}-\mathrm{N}+\mathrm{N}$

$\begin{array}{lll}-\mathrm{P} & 0.84 & 0.86^{*}\end{array}$

$\mathrm{W} \times \mathrm{S}$

$-\mathrm{W}+\mathrm{W}$

$S_{\mathrm{L}} \quad 0.830 .93^{*}$

$\begin{array}{lll}\mathrm{S}_{\mathrm{H}} & 1.04 & 1.03\end{array}$

* and ** denote significance at $\mathrm{P}<0.05$ and 0.01 , respectively.

Source: ICARDA (1984) p. 5-14.

area. They also show that the increases are achieved through the use of very little, if any, extra water. This is critical because the amount of water available to the system is finite. It consists of the current seasonal rainfall plus whatever may be stored in the fallow. Under most seasonal conditions in these areas the amount stored in the fallow is small, although it may at times, in good rainfall years, make a significant contribution to the yield of the subsequent crop (see Fig. 7).

The mechanisms by which fertilizer can increase water use efficiency have been discussed in Section 2 and apply to these results. Two of the datasets in Table 10 were analysed according to the procedure described by Cooper et al. '(1983) which allows crop evapotranspiration to be split into its components of $E_{S}$ and T. Fertilizer application enhanced the rate of canopy development and increased the interception of radiant energy resulting in a considerable reduction in $\mathrm{E}_{\mathrm{S}}$ and corresponding increases in $\mathrm{T}$ (Plate $3 \mathrm{e}$ ). In addition, greater dry matter production during the cold winter months when $\mathrm{e}_{\mathrm{s}}-\mathrm{e}_{\mathrm{a}}$ values are low, and earlier maturity of fertilized crops resulted in larger seasonal transpiration efficiences. The combined effect of fertilizer in reducing the ratio $\mathrm{E}_{\mathrm{S}} / \mathrm{T}$ and increasing transpiration efficiency resulted in substantial improvements in water use efficiency.

In some years, fertilizer application does result in slightly greater water use, particularly at depth within the soil profile. Studies of root growth of barley 
Table 10. The effect of fertilizer $\left(60 \mathrm{~kg} \mathrm{ha} \mathrm{a}^{-1} \mathrm{P}_{2} \mathrm{O}_{5}, 20 \mathrm{~kg} \mathrm{ha}^{-1} \mathrm{~N}\right)$ on yield and components of water use of barley at Breda in NW Syria

\begin{tabular}{|c|c|c|c|c|c|}
\hline Year & $1980 / 81$ & $1981 / 82$ & $1982 / 83$ & $1983 / 84$ & $1984 / 85$ \\
\hline Seasonal rainfall $(\mathrm{mm})$ & 299 & 324 & 284 & 204 & 278 \\
\hline $\begin{array}{l}\text { Total dry matter (kg ha } \\
\text { With fertilizer } \\
\text { Without fertilizer }\end{array}$ & $\begin{array}{l}4940 \\
3550\end{array}$ & $\begin{array}{l}6100 \\
4540\end{array}$ & $\begin{array}{l}4540 \\
2620\end{array}$ & $\begin{array}{l}2880 \\
1340\end{array}$ & $\begin{array}{l}4760 \\
1420\end{array}$ \\
\hline $\begin{array}{l}\text { Grain yield }\left(\mathrm{kg} \mathrm{ha}^{-1}\right) \\
\text { With fertilizer } \\
\text { Without fertilizer }\end{array}$ & $\begin{array}{l}2130 \\
1720\end{array}$ & $\begin{array}{l}2220 \\
1320\end{array}$ & $\begin{array}{l}1740 \\
1040\end{array}$ & $\begin{array}{r}1540 \\
740\end{array}$ & $\begin{array}{r}2380 \\
750\end{array}$ \\
\hline $\begin{array}{l}\mathrm{E}_{\mathrm{S}}+\mathrm{T}(\mathrm{mm}) \\
\text { With fertilizer } \\
\text { Without fertilizer }\end{array}$ & $\begin{array}{l}216 \\
220\end{array}$ & $\begin{array}{l}231 \\
231\end{array}$ & $\begin{array}{l}236 \\
228\end{array}$ & $\begin{array}{l}176 \\
171\end{array}$ & $\begin{array}{l}242 \\
238\end{array}$ \\
\hline $\begin{array}{l}\text { WUE }\left(\mathrm{kg} \mathrm{ha}^{-1} \mathrm{~mm}^{-1}\right) \\
\text { With fertilizer } \\
\text { Without fertilizer }\end{array}$ & $\begin{array}{l}22.9 \\
16.1\end{array}$ & $\begin{array}{l}26.4 \\
19.7\end{array}$ & $\begin{array}{l}19.2 \\
11.5\end{array}$ & $\begin{array}{r}16.3 \\
7.8\end{array}$ & $\begin{array}{r}19.7 \\
6.0\end{array}$ \\
\hline $\begin{array}{l}\mathrm{T}(\mathrm{mm}) \\
\text { With fertilizer } \\
\text { Without fertilizer }\end{array}$ & $\begin{array}{c}108 \dagger \\
83\end{array}$ & $\begin{array}{l}- \\
-\end{array}$ & $\begin{array}{l}86 \ddagger \\
56\end{array}$ & - & - \\
\hline $\begin{array}{l}\mathrm{E}_{\mathrm{S}}(\mathrm{mm}) \\
\text { With fertilizer } \\
\text { Without fertilizer }\end{array}$ & $\begin{array}{l}108 \\
137\end{array}$ & - & $\begin{array}{l}150 \\
172\end{array}$ & - & - \\
\hline $\begin{array}{l}\mathrm{E}_{\mathbf{S}} / \mathrm{T} \\
\text { With fertilizer } \\
\text { Without fertilizer }\end{array}$ & $\begin{array}{l}1.00 \\
1.65\end{array}$ & - & $\begin{array}{l}1.74 \\
3.07\end{array}$ & - & - \\
\hline $\begin{array}{c}\mathrm{TE}\left(\mathrm{kg} \mathrm{ha}^{-1} \mathrm{~mm}^{-1}\right) \\
\text { With fertilizer } \\
\text { Without fertilizer }\end{array}$ & $\begin{array}{l}45.7 \\
42.8\end{array}$ & - & $\begin{array}{l}52.8 \\
46.8\end{array}$ & - & - \\
\hline
\end{tabular}

Source: † Cooper et al. (1983); † Cooper et al. (1987).

have shown that this increased extraction of water is associated with greater root length densities when fertilizer is applied (Gregory et al., 1984; Brown et al., 1987; Cooper et al., 1987; Fig. 10).

In the $1 \overline{9} 82 / 83$ season, the technology of fertilizer use $\left(60 \mathrm{~kg} \mathrm{ha}^{-1} \mathrm{P}_{2} \mathrm{O}_{5}\right)$ was tested in simple farmer-managed trials on eight farms near Breda and Khanasser. In these trials, large plots were used $\left(1000 \mathrm{~m}^{2}\right)$ and the farmer was responsible for land preparation, sowing, fertilizer applications and harvesting, whilst ICARDA provided the fertilizer and recorded grain and straw yields. These trials have been reported elsewhere (ICARDA, 1984. pp. 18-20) but in summary, the application of phosphate fertilizer increased mean grain and straw yields from 800 and $1075 \mathrm{~kg} \mathrm{ha}^{-1}$ to 1200 and $1640 \mathrm{~kg} \mathrm{ha}^{-1}$, respectively, across all locations.

\section{Collaboration with the Syrian National Programme}

The data from the experimental programme and farmer-managed trials indicated that the use of fertilizer on barley in these marginal areas was biologically and economically sound. In March 1984 a workshop was jointly organized by ICARDA and the Syrian Soils Directorate which carries the responsibility of formulating fertilizer recommendations. Representatives from the Ministry of 
Planning, the Agricultural Research Corporation, the Extension Bureau and the University of Aleppo were also invited. Eleven papers were presented which reviewed the socio-economic conditions of barley growers, the soils and climate of the project area, the chemistry of soil/phosphate fertilizer reactions and the effect of fertilizer use on the growth (root and shoot) of barley, its water use and the economic returns. Participants spent one day in the field discussing on-going research trials.

In the final session, the participants concluded that 'so far, the dryland regions have received very little attention with respect to national planning and resource allocation, and that more consideration should be directed towards these areas.' It was agreed that a collaborative research programme (Soils Directorate/ICARDA) should be started to investigate the economic potential of fertilizer use on barley on a nationwide basis in order to provide fertilizer recommendations for barley growers. A full report of this workshop has been published in Arabic and English (Soils Directorate/ICARDA, 1984).

\section{Soils Directorate/ICARDA collaborative research}

In September 1984, at a joint Ministry of Agriculture/ICARDA planning session, the details of the collaborative programme of research on the use of fertilizer on barley were agreed.

Fifteen farmers' fields were selected in the four major barley producing provinces of Hama, Aleppo, Raqqa and Hassakeh. In the first year, sites were selected which were flat with deep soil (more than $1 \mathrm{~m}$ ) which had been fallowed in the preceding season. Detailed soil analyses to a depth of $100 \mathrm{~cm}$ were undertaken prior to sowing at each site, and a rain guage was installed and recorded weekly.

The $4 \times 4$ factorial trial was laid out in a two-replicated randomized complete block design with four levels of nitrogen fertilizer $(0,20,40$ and $60 \mathrm{~kg}$ $\left.\mathrm{ha}^{-1} \mathrm{~N}\right)$ and four levels of phosphorus $\left(0,30,60\right.$ and $\left.90 \mathrm{~kg} \mathrm{ha}^{-1} \mathrm{P}_{2} \mathrm{O}_{5}\right)$. Seedbed preparation was done by the farmers and the plots $(2.1 \times 12.5 \mathrm{~m})$ were drill sown with the local landrace barley (Arabic Aswad) at $100 \mathrm{~kg} \mathrm{ha}^{-1}$ of seed. All the phosphorus and half the nitrogen was drilled with the seed and the remaining $\mathrm{N}$ top-dressed at the tillering stage. Weeds were not a serious problem, but were controlled by a single application of Brominal Plus (Brominoxyl plus MCPA) also at tillering.

The growth of the crop was monitored by sampling at tillering, anthesis and maturity, and full components of yield were recorded. In addition, economic surveys were conducted in the nearby villages to assess local costs and prices to allow accurate analyses of the economics of fertilizer use. Full details of the methodology and results have been reported in detail (ICARDA, 1986) and only the highlights are summarized here.

Eleven of the fifteen trials were successfully harvested, and significant grain yield and total dry matter responses to nitrogen or phosphorus or both were found at all locations (Plate 3f). 
In addition to single site analyses, the data were pooled within the two agricultural climatic zones defined by the Syrian Ministry of Agriculture (Zone 2: 250-350 mm mean annual rainfall with more than $250 \mathrm{~mm}$ in two-thirds of years; Zone 3: more than $250 \mathrm{~mm}$ mean annual rainfall with more than 250 $\mathrm{mm}$ in half the years).

The pooled data were subjected to analyses of co-variance using three rainfall terms (start of season to tillering, tillering to anthesis, and anthesis to maturity), initial available- $\mathrm{P}$ and mineral $\mathrm{N}$ as co-variates. Adjusted mean components of yield data were calculated from the results of these analyses using standard methods. The analyses for total dry matter are presented in Fig. 12. In the wetter Zone 2, the major response was to nitrogen application, whereas in the drier Zone 3, the response was principally to phosphate. Economic analyses for Zones 2 and 3, using data collected in the surveys, confirmed that fertilizer use in these dry areas is well worthwhile (Fig. 13).

Zone 2
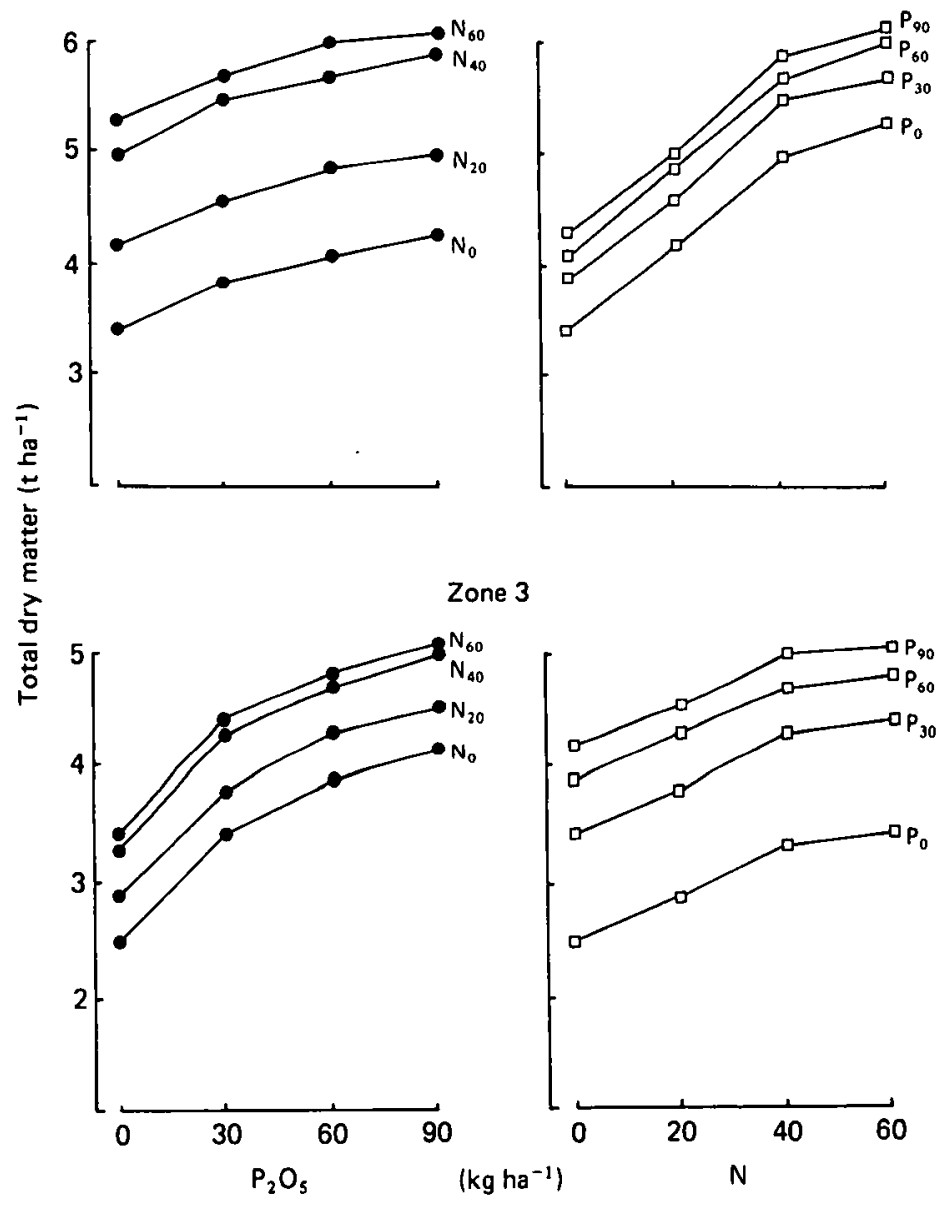

Zone 3

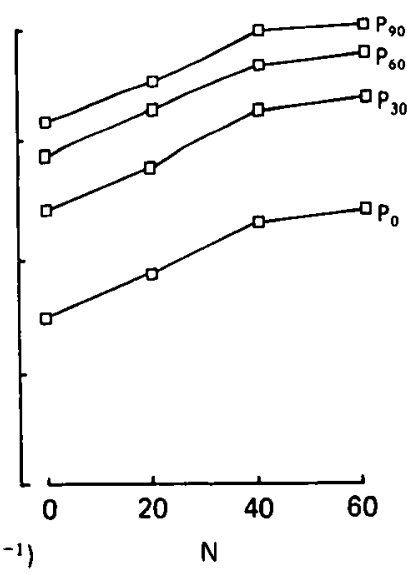

Fig. 12. Response of total dry matter yields of barley (var. Arabic Aswad) to $\mathrm{P}_{2} \mathrm{O}_{3}(\bullet-\bullet: 0,30,60$ and $90 \mathrm{~kg} \mathrm{ha}^{-1}$ ) and $\mathrm{N}$ ( $\mathrm{O}-\mathrm{o}: 0,20,40$ and $60 \mathrm{~kg} \mathrm{ha}^{-1}$ ) fertilizer in Zones 2 and 3 in Syria, 1984/85. Responses have been adjusted for the effects of rainfall and soil available $\mathrm{P}$ and $\mathrm{N}$. 
In conclusion, the first season's results confirmed that substantial and highly profitable responses to fertilizer were as widespread as anticipated, and even after one year's cooperative research, three important results emerged. First, $70 \%$ of the farmers who were involved in or saw the trials indicated that they were interested in using fertilizer on barley in the next season. Secondly, the Soils Directorate instructed, for the first time, that fertilizer should be applied to barley on Government State Farms in Zones 2 and 3, and thirdly, credit facilities will be made available to farmers in Zone 3, again for the first time.

\section{On-going research}

Following the success of this cooperative work, the project was expanded in the $1985 / 86$ season to thirty farmers' fields. On-going research has indicated that fertilizer response is markedly affected by the crop rotation practised by the farmer (continuous barley or fallow/barley), greater responses to nitrogen being found in the continuous barley system. Total dry matter responses of

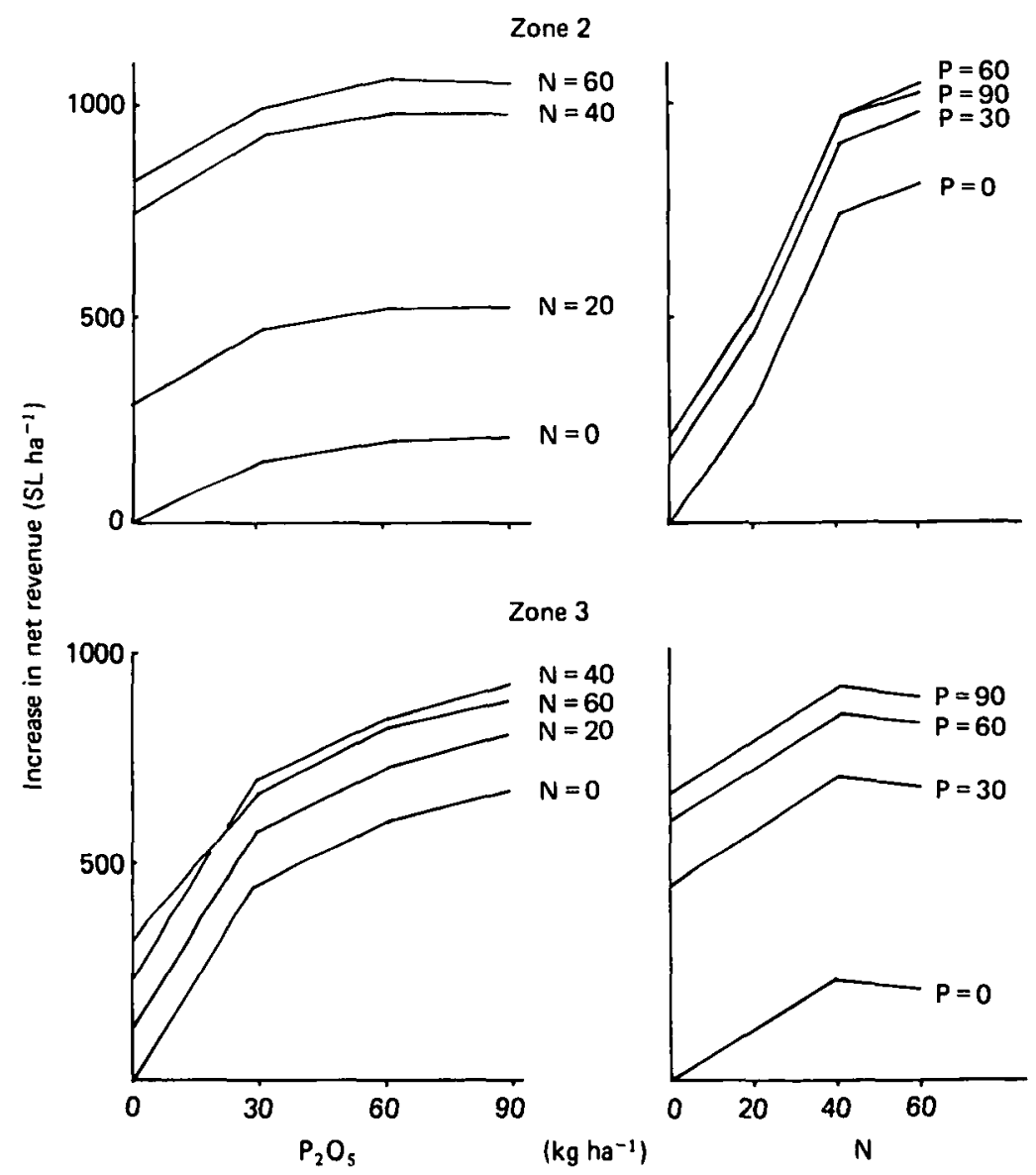

Fig. 13. Increase in net revenue as a result of fertilizer use in Zones 2 and 3 in Syria, 1984/85. Net revenues calculated on grain straw yield responses adjusted for the effects of rainfall and soil available $\mathrm{P}$ and $\mathrm{N}$. $10 \mathrm{SL}=1 \mathrm{US} \$$ approx. 
barley at Breda to nitrogen and phosphorus fertilizer are illustrated in Fig. 14 for two years of contrasting rainfall (see Table 10). The response surfaces are obtained from regression equations fitted to the field data (see insert tables), and it can be seen that in both years responses to nitrogen were substantial under continuous barley, but not in the fallow/barley rotation, although an $\mathrm{N} \times \mathrm{P}$ interaction was observed in the wetter year of 1984/85. In addition, responses to residual phosphate will further enhance the economics of fertilizer use and, as indicated earlier, soil depth will affect the length of growing season and thus the potential for crop growth and response to fertilizer. Thus in the

$1983 / 84$
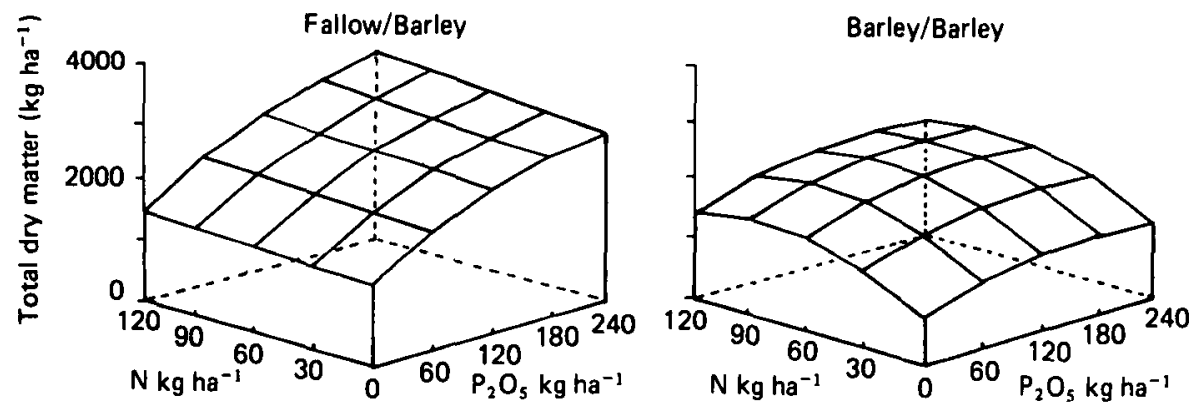

\begin{tabular}{|c|c|c|c|c|c|c|c|}
\hline & Constant & $P$ & $N$ & $\mathrm{NP}$ & $N^{2}$ & $\mathrm{P}^{2}$ & $\bar{A}^{2}$ \\
\hline F/B & 1353 & $\begin{array}{r}10.0 \\
\times \times x \times \\
\end{array}$ & $\begin{array}{l}1.4 \\
\mathrm{~ns}\end{array}$ & $\begin{array}{c}0.008 \\
\mathrm{~ns}\end{array}$ & $\begin{array}{c}-0.002 \\
\mathrm{~ns}\end{array}$ & $\mid \begin{array}{c}-0.020 \\
x \times x\end{array}$ & 0.85 \\
\hline $8 / 8$ & 758 & $\begin{array}{r}\mathbf{5 . 5} \\
\times x\end{array}$ & $\begin{array}{r}18.9 \\
\times \times x\end{array}$ & $\begin{array}{c}0.003 \\
\mathrm{~ns}\end{array}$ & -0.115 & $\begin{array}{c}-0.015 \\
x x\end{array}$ & 0.68 \\
\hline
\end{tabular}
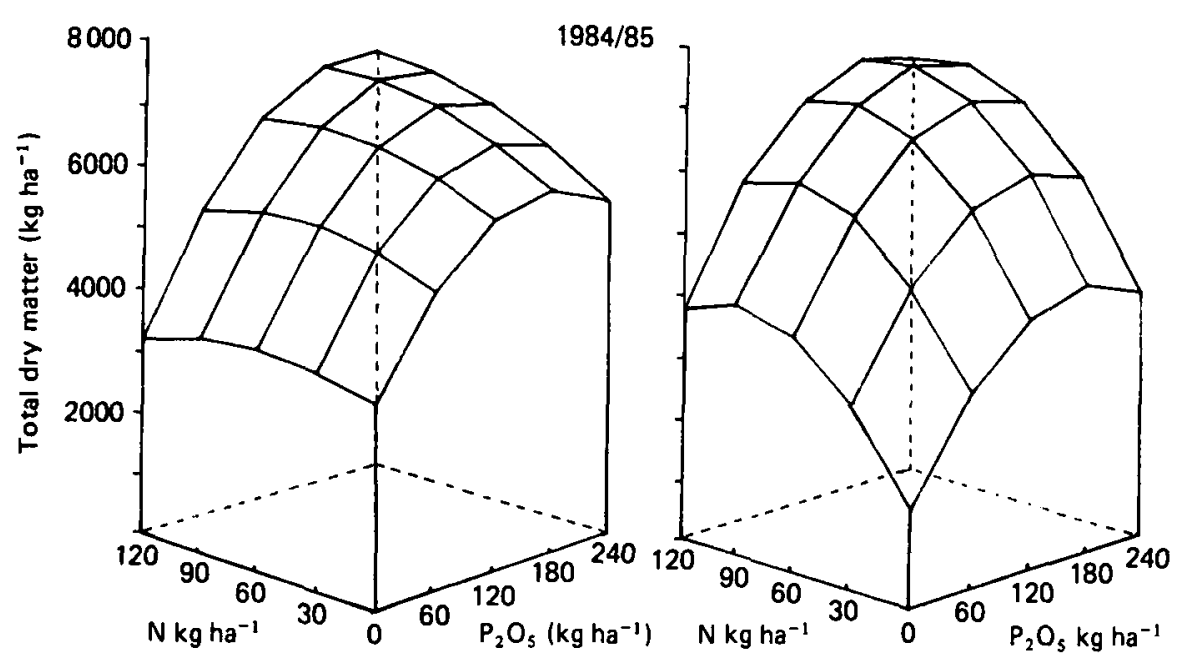

\begin{tabular}{|c|c|c|c|c|c|c|c|}
\hline & Constant & $P$ & $N$ & $N P$ & $\mathrm{~N}^{2}$ & $p^{2}$ & $\overline{\mathrm{A}}^{2}$ \\
\hline$F / B$ & 3320 & \begin{tabular}{|l}
29.6 \\
$\times \times x \times$ \\
\end{tabular} & $\begin{array}{c}11.5 \\
\mathrm{~ns}\end{array}$ & $\begin{array}{r}0.08 \\
\times \times 8 \\
\end{array}$ & $\begin{array}{c}-0.11 \\
\mathrm{~ns}\end{array}$ & $\begin{array}{r}-0.00 \\
x \times x \\
\end{array}$ & 0.81 \\
\hline$B / 8$ & 1815 & $\begin{array}{r}30.5 \\
\times \times x\end{array}$ & $\begin{array}{r}54.0 \\
\times \times x\end{array}$ & $\begin{array}{c}0.03 \\
\mathrm{~ns}\end{array}$ & $\begin{array}{r}-0.31 \\
\times \times x\end{array}$ & $\begin{array}{r}-0.00 \\
x \times x\end{array}$ & 0.78 \\
\hline
\end{tabular}

Fig. 14. Effect of crop rotation and year on the response surface of total dry matter production of barley to $\mathrm{N}$ and $\mathrm{P}$ fertilizer at Breda, NW Syria. Insert tables give respective regression equations with levels of significance, $* * * P<0.01, * * P<0.05$, ns not significant. 
expanded programme, the trial design and management remain the same, but comparisons will be made of the fertilizer response within barley/barley and fallow/barley rotations and on deep and shallow soils. In addition, the residual effects of fertilizer from the 1984/85 set of trials will be assessed at selected locations.

If this project is successful in allowing the Syrian Government to produce fertilizer recommendations for the dryland barley growing areas and to formulate agriculture policies to encourage and facilitate their adoption, the impact on the welfare of the farmers in these areas and their farm productivity is likely to be substantial. We feel this would provide a great incentive for other national programmes in west Asia and north Africa to allocate greater research and development priority to the dryland barley/livestock systems of the region.

\section{CONCLUSIONS}

Rainfed agricultural systems still predominate in the Mediterranean region and will continue to do so in the foreseeable future. Given the overall constraint of a limited and erratic supply of water for crop production in such systems, high priority should be given to research and development projects which focus on improving the efficiency of water use. In the short and medium terms, it is clear that improved crop and soil management can achieve substantial increases in crop yields and water use efficiency, but longer term research should seek to utilize genotypic differences in the physiological characteristics of plants to identify improved cultivars which have large and stable yields and high water use efficiency.

The majority of farmers in the region are smallholders with less than 10 ha of land and in many instances they face financial constraints which inevitably hinder the adoption of new technologies. In addition livestock husbandry is closely integrated with crop production and will play an important role in the farmer's decision making process. We believe that a systems approach is essential in defining the objectives of relevant and workable programmes of research.

Finally, the problems of improving the water use efficiency of crop production are similar, not only within the countries of the Mediterranean region, but also in other regions of the world with similar climates. We firmly believe that collaboration and free exchange of information between scientists working in such environments will allow a more rapid solution to the food production problems which the region is currently experiencing.

Acknowledgements. Many research scientists have been involved in the work reported in the final section of this review and cannot be listed by name. The authors gratefully acknowledge their input, and especially the enthusiastic cooperation and support of the staff of the Syrian Soils Directorate.

Financial support for P.J.G. was provided by The Overseas Development 
Administration and much of the soil water and nutrient research at ICARDA was funded by UNDP. Both are gratefully acknowledged.

\section{REFERENCES}

Anderson, W. K. (1984). Plant populations for triticale in a Mediterranean environment. Field Crops Research 8:281-95.

Anderson, W. K. (1985a). Production of green feed and grain from grazed barley in northern Syria. Field Crops Research 10:57-75.

Anderson, W. K. (1985b). Grain yield responses of barley and durum wheat to split nitrogen applications under rainfed conditions in a Mediterranean environment. Field Crops Research 12:191-202.

AOAD (Arab Organization for Agricultural Development, League of Arab States) (1984). 1983 Yearbook of Agricultural Statistics, Vol. 3. Khartoum: AOAD.

Aricanli, T. \& Somel, K. (1979). Observations on developments in agriculture and land distribution in Turkey. (In Turkish). Studies in Development 6:91-110.

Aschmann, H. (1977). Historical development of agriculture in semi arid regions of winter precipitation. In Proceedings International Symposium on Rainfed Agriculture in Semi Arid Regions, Riverside, Califormia, U.S.A., April 1977.

Bakhtri, N. (1979). Introduction of the medic/wheat rotation in the North African and Near East countries. In Proceedings of the FAO Regional Seminar on Rainfed Agriculture in the Near East and North Africa, Amman, Jordan, May 5-10, 1979, 118-125.

Benzaghou, M. M. (1979). Situation des cereales en Algerie. In Proceedings of the Fifth Regional Workshop, Ministry of Agriculture and Agrarian Revolution, Algeria; CIMMYT (Mexico City) and ICARDA (Aleppo, Syria), Algiers, 5-9 May 1979, Vol. 1, 15-21.

Bierhuizen, J. F. \& Slatyer, R. O. (1965). Effect of atmospheric concentration of water vapour and $\mathrm{CO}_{2}$ in determining transpiration-photosynthesis relationships of cotton leaves. Agricultural Meteorology $2: 259-70$.

Bolton, F. E. (1981). Optimizing the use of water and nitrogen through soil and crop management. Plant and Soil 58:231-248.

Brichambaut, G. de \& Wallen, G. (1963). A study of agroclimatology in the semi-arid and arid zones of the Near East. Technical Note 56. Geneva: WMO.

Bristow, K. L., Campbell, G. S., Papendick, R. I. \& Elliott, L. F. (1986). Simulation of heat and moisture transfer through a surface residue-soil system. Agricultural and Forest Meteorology 36:193-214.

Brouwer, R. (1963). Some physiological aspects of the influence of growth factors in the root medium on growth and dry matter production. Jaarb. Institute Biologie Scheik Onderz LandbGewass, 1963, 11-30.

Brown, P. L. (1971). Water use and soil water depletion by dryland winter wheat as affected by nitrogen fertilization. Agronomy Journal 63:43-46.

Brown, S. C., Keatinge, J. D. H., Gregory, P. J. \& Cooper, P. J. M. (1987). Effects of fertilizer, variety and location on barley production under rainfed conditions in Northern Syria. 1. Root and shoot growth. Field Crops Research (In press).

Campbell, R. R., Follet, R. H., Howell, H. B., Riddle, R., Stubbendieck, J. T. \& Hamway, D. G. (1977). Applied agronomic research program for dryland farming in 200-400 mm rainfall zone of Morocco. Publication No. PN-AAF-329. Washington, D. C.: USAID.

Caprio, J. M., Grunwald, G. K. \& Synder, R. D. (1985). Effect of standing stubble on soil water loss by evaporation. Agricultural and Forest Meteorology 34:129-144.

Cooper, P. J. M. (1983). Crop management in rainfed agriculture with special reference to water use efficiency. In Proceedings of the 17 th Colloquium of the International Potash Institute, Rabat, Morocco, May 1983, 19-35.

Cooper, P. J. M., Allan, A. Y., Harmsen, K., Keatinge, J. D. H., Nygaard, D., Saxena, M. \& Islam, R. (1981). Soil water and nutrient research. 1979-80. ICARDA Project Report No. 3. Aleppo, Syria: ICARDA.

Cooper, P. J. M., Gregory, P. J., Keatinge, J. D. H. \& Brown, S. C. (1987). Effects of fertilizer, variety and location on barley production under rainfed conditions in northern Syria. 2. Soil water dynamics and crop water use. Field Crops Research (In press).

Cooper, P. J. M., Keatinge, J. D. H. \& Hughes, G. (1983). Crop evapotranspiration - a technique for calculation of its components by field measurements. Field Crops Research 7:299-312.

Day, W., Legg, B. J., French, B. K. Johnstone, A. E., Lawlor, D. V. \& de Jeffers, W. (1978). A drought experiment using mobile shelters: the effect of drought on barley yield, water use and nutrient uptake. Journal of Agricultural Science, Cambridge 91:599-623. 
Dennett, M. D., Rodgers, J. A. \& Keatinge, J. D. H. (1983). Simulation of a rainfall record for the site of a new agricultural development: an example from Northern Syria. Agricultural Meteorology 29: 247-58.

Doren, D. M. van \& Allmaras, R. R. (1978). Effect of residue management practices on the soil physical environment, microclimate and growth. In Crop Residue Management Systems, Agronomy Monograph No. 31, 49-83. Madison: American Society of Agronomy.

El-Fauly, M. M. (1983). Micronutrients in arid and semi arid areas: levels in soils and plants and the need for fertilizers with reference to Egypt. In Proceedings of the 17th Colloquium of the International Potash Institute, Rabat, Morocco, May 1983, 163-174.

FAO (1978). Report on the agro-ecological zones project, Vol. 1. Methodology and results for Africa. World Soils Resources Report 48/1. Rome: FAO.

FAO (1979). Report on the agro-ecological zones project, Vol. 2. Results for South West Asia. World Soils Resources Report, 48/2. Rome: FAO.

FAO (1984). 1983 FAO Production Yearbook, Vol. 37. Rome: FAO.

Farquhar, G. D. \& Richards, R. A. (1984). Isotopic composition of plant carbon correlates with wateruse efficiency of wheat genotypes. Australian Joumal of Plant Physiology 11:539-52.

Fischer, R A. (1981). Optimizing the use of water and nitrogen through the breeding of crops. Plant and Soil 58:249-78.

Fischer, R. A. \& Kohn, G. D. (1966). The relationship of grain yield to vegetative growth and post flowering leaf area in the wheat crop under conditions of limited soil moisture. Australian Joumal of Agricultural Research 17:281-295.

French, R. J. \& Schultz, F. E. (1984). Water use efficiency of wheat in a Mediterranean-type environment. 1. The relation between yield, water use and climate. Australian Joumal of Agricultural Research 35:743-64.

Ghanem, H., Amnai, L., Azzaoui, H., Bouksirat, H., El Gharous, M. \& Oubakammou, S. (1983). Nitrogen, phosphate and potassium and management of arid and semi arid soils of Morocco - Preliminary results of a large scale project. In Proceedings of the 17 th Colloquium of the Intemational Potash Institute, Rabat, Morocco, May 1983, 259-278.

Gibbon, D. (1981). Rainfed farming systems in the Mediterranean region. Plant and Soil 58:59-80.

Goudriaan, J. \& van Laar, H. H. (1978). Relations between leaf resistance, $\mathrm{CO}_{2}$-concentration, and $\mathrm{CO}_{2}$ assimilation in maize, beans, lalang grass and sunflower. Photosynthetica 12:241-249.

Gregory, P. J. (1984). Water availability and crop growth in arid regions. Outlook on Agriculture 13: 208-215.

Gregory, P. J., Shepherd, K. D. \& Cooper, P. J. M. (1984). Effects of fertilizer on root growth and water use of barley in northern Syria. Journal of Agricultural Science, Cambridge 103:429-38.

Grigg, D. (1974). Farming Systems of the World. Cambridge: Cambridge University Press.

Guler, M., Unver, I., Pala, M., Duratan, N. \& Karaca, M. (1979). The fallow system and cereal production in the dryland areas of Turkey. In Proceedings of the Fifth Regional Workshop, Algiers, 5-9 May 1979. Ministry of Agriculture and Agrarian Revolution, Algeria; CIMMYT (Mexico City) and ICARDA (Aleppo, Syria). Vol 2, 75-86.

Haddad, G. A. Chaudhry, F. M., Haque, I. \& Khan, G. A. (1979). Effect of micronutrient fertilization on various legumes and cereals in the Kufra Oasis. In Proceedings of 3rd Symposium of C.I.E.C. on Water and Fertilizer Use for Food Production in Arid and Semi-arid Zones, 303-308 (Ed. E. Weltze). Gottingen: CIEC.

Harison, H., Borlaug, N. E. \& Anderson, R. G. (1982). Wheat in the Third World. Boulder, Colorado: Westview.

Harmsen, K. (1984a). Dryland barley production in Northwest Syria. I. Soil conditions. In Proceedings of Soils Directorate/ICARDA Workshop on Fertilizer Use in Dry Areas, March 1984, Aleppo, Syria, 12-41.

Harmsen, K. (1984b). Dryland barley production in Northwest Syria. II. Chemistry and fixation of phosphorus in calcareous soils. In Proceedings of Soils Directorate/ICARDA Workshop on Fertilizer Use in Dry Areas, March 1984, Aleppo, Syria, 42-67.

Harmsen, K., (1984c). Nitrogen fertilizer use in rainfed agriculture. Fertilizer Research 5:371-382.

Harmsen, K., Shepherd, K. D. \& Allan, A. Y. (1983). Crop response to nitrogen and phosphorus in rainfed agriculture. In Proceedings of the 17 th Colloquium of the International Potash Institute, Rabat, Morocco, May 1983, 223-248.

Hepworth, H. M., Zinn, T. G. \& Anderson, W. L. (1975). Improved Techniques for Dryland Agriculture Means More Wheat from Fallow Farming. (2nd Edition). Ankara, Turkey: USAID/Oregon State University Team.

Hogan, E. B., Furtick, W. R. \& Grayzel, J. A. (1984). Morocco Increase in Cereal Production. Report to USAID, Washington, D. C.

ICARDA (1982). Annual Report, 1981. Aleppo, Syria: International Centre for Agricultural Research in Dry Areas. 
ICARDA (1983). Annual Report 1982. Aleppo, Syria: International Centre for Agricultural Research in Dry Areas.

ICARDA (1984). Annual Report 1983. Aleppo, Syria: International Centre for Agricultural Research in Dry Areas.

ICARDA (1985). Annual Report 1984. Aleppo, Syria: International Centre for Agricultural Research in Dry Areas.

ICARDA (1986). Annual Report 1985. Aleppo, Syria: International Centre for Agricultural Research in Dry Areas.

Ismail, H. N. (1974). Water use efficiency of wheat, linseed and cotton grown in the central region of Iraq. Iragi Journal of Agricultural Science 9:18-26.

Janssen, B. H. (1972). The significance of the fallow year in the dry-farming system of the Great Konya Basin, Turkey. Netherlands Journal of Agricultural Science 20:247-260.

Jaubert, R. \& Oglah, M. (1985). Farming systems management in the Bueda/Breda sub area $1983 / 84$. ICARDA Research Report. Aleppo, Syria: ICARDA.

Jaubert, R. \& Thomson, E. (1985). Sheep feeding strategies at Bueda, N.W. Syria. In ICARDA Annual Report 1984, 29-33. Aleppo, Syria: ICARDA.

Kallsen, C. E., Sammis, T. W. \& Gregory, E. J. (1984). Nitrogen and yield as related to water use of spring barley. Agronomy Journal 76:59-64.

Karouzis, G. (1980). Report on Aspects of Land Tenure in Cyprus. (2nd Edition). Nicosia: Ministry of Agriculture and Natural Resources.

Kassam, A. H. (1981). Climate, soil and land resources in North Africa and West Asia. Plant and Soil $58: 1-29$.

Keatinge, J. D. H. \& Cooper, P. J. M. (1983). Kabuli chickpea as a winter sown crop in northern Syria: moisture relations and crop productivity. Journal of Agricultural Science, Cambridge 100:667-680.

Keatinge, J. D. H., Dennett, M. D. \& Rodgers, J. (1985). The influence of precipitation regime on the management of three course crop rotations in Northern Syria. Journal of Agricultural Science, Cambridge 104:281-287.

Keatinge, J. D. H., Neate, P. J. H. \& Shepherd, K. D. (1985). The role of fertilizer management in the development and expression of crop drought stress in cereals under Mediterranean environmental conditions. Experimental Agriculture 21:209-22.

Ketata, H., Halila, H., Deghaies, M., Maamourie, A. \& Harrabi, M. (1979). La productione cerealiere en Tunisie. In The Proceedings of the Fifth Regional Cereals Workshop, Algiers, 5-9 May 1979. Ministry of Agriculture and Agrarian Revolution: Algeria, CIMMYT (Mexico City), and ICARDA (Aleppo, Syria). Vol. I, 53-59.

Keulen, H. van. (1977). On the role of nitrogen in semi-arid regions. Stikstof No. 20:23-28.

Lindstrom, M. J., Koehler, F. E. \& Papendick, R. I. (1974). Tillage effects on fallow water storage in the eastern Washington dryland region. Agronomy Journal 66:312-316.

Loizides, P. (1979). Crop rotations under rainfed conditions in a Mediterranean climate in relation to soil moisture and fertilizer requirements. In Proceedings of the FAO Regional Seminar on Rainfed Agriculture in the Near East and North A frica, Amman, Jordan, 5-10 May 1979, 23-38.

Matar, A. (1986). Annual Report 1985. Aleppo, Syria: International Centre for Agricultural Research in Dry Areas.

Mazad, A. \& Hallajian, M. (1983). Crop-livestock interactions: information from a barley survey in Syria. In ICARDA Regional Farming Systems Workshop, May 1983, Aleppo, Syria.

McWilliam, J. R. (1981). Prologue: context and scope. In Soil Water and Nitrogen in Mediterranean-type Environments. Plant and Soil 58:vii-x.

Meigs, P. (1964). Classification and occurrence of Mediterranean-type dry climates. In Land Use in Semi Arid Mediterranean Climates. Arid Zone Research 26. Paris: UNESCO.

Miladi, S., (1983). The state of food and nutrition in the Middle East. In Interfaces between Agriculture, Food Science and Nutrition, 35-54 (Eds S. Miladi, S. Mahgoub and P. Neate). Aleppo, Syria: ICARDA.

Mokbel, M. G. (1985). Evaluation of nutritionally relevant indicators in villages in Aleppo Province, Syria, and their relation to agricultural development. PhD Thesis, University of Massachusetts, USA.

Newburg, R., Sleeper, J., Eighmy, T., Hanafi, M., Ream, H., Segal, J. \& Hyslop, J. (1982). Rainfed agriculture sub-sector strategy, technical appendices. Morocco CDSS, USAID, Washington D.C.

Nordblom, T. L. (1983). Livestock-crop interactions: the decision to harvest or to graze mature grain crops. Discussion Paper 10. FSP. Aleppo, Syria: ICARDA.

Oram, P. (1979). Crop production systems in the arid and semi arid warm temperate and Mediterranean zones. In Soil, Water and Crop Production, 193-228 (Eds D. W. Thorne and M. D. Thorne). Westport, Connecticut: AVI Publishing Co.

Papachristodoulou, S. (1979). Socio-economic aspects of rainfed agriculture in Cyprus. In Proceedings of the FAO Regional Seminar on Rainfed Agriculture in the Near East and North Africa, Amman, Jordan, May 5-10, 1979, 327-337. 
Papendick, R. I. \& Campbell, G. S. (1974). Wheat-fallow agriculture: why, how, when? In Proceedings 2nd Regional Wheat Workshop, Ankara, Turkey, 1974.

Pearcy, R. W. \& Ehleringer, J. (1984). Comparative ecophysiology of $\mathrm{C}_{3}$ and $\mathrm{C}_{4}$ plants. Plant, Cell and Environment 7:1-13.

Penman, H. L \& Schofield, R. K. (1951). Some physical aspects of assimilation and transpiration. Symposium of The Society of Experimental Biology V:115-29.

Perrier, A. (1973). Bilan hydrique de l'assolement ble-jachere et evaporation d'un sol nu, en region semiaride. In Response of Plants to Climatic Factors, Uppsala, 1970, 477-487. Paris: Unesco.

Photiades, T. (1979). Integration of livestock with rainfed agriculture in Cyprus. In Proceedings of the FAO Regional Seminar on Rainfed Agriculture in the Near East and North Africa, Amman, Jordan, 5-10 May, 1979, 108-117.

Ramig, R. E. \& Rhoades, H. F. (1962). Interrelationships of soil moisture level at planting time and nitrogen fertilization on winter wheat production. Agronomy Joumal 54:123-127.

Rassam, A. \& Tully, D. (1986). Annual Report 1985. Aleppo, Syria: International Centre for Agricultural Research in Dry Areas.

Ritchie, J. T. (1983). Efficient water use in crop production: discussion on the generality of relations between biomass production and evapotranspiration. In Limitations to Efficient Water Use in Crop Production, 29-43 (Eds M. H. Taylor, W. R. Jordan and R. T. Sinclair). Madison: American Society of Agronomy.

Russell, R. S. (1977). Plant Root Systems: their Function and Interaction with the Soil, 19-29. England: McGraw Hill Book Co.

Saab, G. (1973). Lebanon. In International Association of Agricultural Economists. World Atlas of Agriculture. Vol 2: South and East Asia, 350-360. Novara, Italy: Instituto Geografico de Agostini.

Sabet, Y. \& Harris, H. C. (1986). Annual Report 1985. Aleppo, Syria: International Centre for Agricultural Research in Dry Areas.

Shepherd, K. D., Cooper, P. J. M., Allan, A. Y., Drennan, D. S. H. \& Keatinge, J. D. H. (1987). Growth, water use and yield of barley in Mediterranean-type environments. Journal of Agricultural Science, Cambridge 108 (In press).

Simmonds, N. W. (1986). A short review of farming systems research in the tropics. Experimental Agriculture 22:1-13.

Sivakumar, M. V. K. \& Huda, A. K. S. (1983). Potential agricultural productivity in summer and winter rainfall areas. In Proceedings of the 17th Colloquium of the International Potash Institute, Rabat, Morocco, May 1983, 23-47.

Smith, A. J. (1979). The integration of livestock into rainfed agricultural systems. In Proceedings of the FAO Regional Seminar on Rainfed Agriculture in the Near East and North Africa, Amman, Jordan, May 5-10, 1979, 139-152.

Smith, R. C. G. \& Harris, H. C. (1981). Environmental resources and restraints to agricultural production in a Mediterranean-type environment. Plant and Soil 58:31-57.

Soils Directorate/ICARDA (1984). Proceedings of the Soils Directorate/ICARDA Workshop on Fertilizer Use in the Dry Areas. March 26th-29ih, 1984, ICARDA, Aleppo, Syria.

Somel, K., Mazid, A. \& Hallajian, M. (1984). Survey of barley producers in northern Syria 1981/82. Volume III: descriptive statistics. ICARDA Research Report 12. Aleppo, Syria: ICARDA.

Stapper, M. \& Goebel, W. (1985). Annual Report 1984, 50-53. Aleppo, Syria: International Centre for Agricultural Research in Dry Areas.

Taha, M. F., Harb, S. A., Nagib, M. K. \& Tantawy, A. M. (1981). The climate of the Near East. In Climates of Southern and Western Asia. World Survey of Climatology, Vol. 9, 183-256. Amsterdam: Elsevier Scientific Publishing.

Tamini, S. A. \& Young, J. R. W. (1980). Preliminary soil moisture studies at Hamman Al-Alil, Northern Iraq. In Proceedings of the FAO Regional Seminar on Rainfed Agriculture in the Near East and North Africa, Amman, Jordan, 5-10 May, 1979, 239-47.

Tanner, C. B. \& Sinclair, T. R. (1983). Efficient water use in crop production: research or re-search? In Limitations to Efficient Water Use in Crop Production, 1-27 (Eds H. M. Taylor, W. R. Jordan and T. R. Sinclair). Madison: American Society of Agronomy.

Tennant, D. (1981). Effect of fallowing on cereal yield. Joumal of Western Australia Department of Agriculture 22:38-41.

Thomson, E., Jaubert, R. \& Oglah, M. (1986). Annual Report 1985. Aleppo, Syria: International Centre for Agricultural Research in Dry Areas.

Tully, D. (1984). Land use and farmer strategies in Al Bab: the feasibility of forage legumes in the place of fallow. ICARDA Research Report No. 13, Aleppo, Syria: ICARDA.

Tully, D. (1985). Annual Report 1984, p. 35. Aleppo, Syria: International Centre for Agricultural Research in Dry Areas.

Tully, D. (1986). Rainfed farming systems of the Near East region. In Proceedings of Workshop on Soi, 
Water and Crop/Livestock Systems for Rainfed Agriculture in the Near East Region, Amman, Jordan, January 1986.

Ulusan, A. (1980). Public policy toward agriculture and its redistributive implications. In The Political Economy of Income Distribution in Turkey, 125-167 (Eds E. Ozbudun and A. Ulusan). New York: Holmes and Meier.

UNESCO/FAO (1963). Bio-climatic map of the Mediterranean zone. Arid Zone Research 21. Paris: UNESCO.

Vlek, P. L G., Fillery, I. R. P. \& Burford, J. R. (1981). Accession, transformation and loss of nitrogen in soils of the arid region. Plant and Soil 58:133-176.

Walker, G. K. \& Richards, J. E. (1985). Transpiration efficiency in relation to nutrient stress. Agronomy Journal 77:263-269.

Watson, A., 1974. The Arab agricultural revolution and its diffusion. 700-1100. Journal of Economic History, 34, No. 1.

White, H. (1963). Roman Agriculture in North Africa. Nigeria Geographical Journal 6:39-49.

White, H. (1970). Fallowing, crop rotation and crop yields in Roman times. Agricultural History 44: 281-290.

Wong, S. C., Cowan, I. R. \& Farquhar, G. D. (1979). Stomatal conductance correlations with photosynthetic capacity. Nature 282:424-6. 